\title{
Crustal-scale seismic profiles across Taiwan and the western Philippine Sea
}

\author{
Kirk McIntosh ${ }^{\mathrm{a}, *}$, Yosio Nakamura ${ }^{\mathrm{a}}$, T.-K. Wang ${ }^{\mathrm{b}}$, R.-C. Shih ${ }^{\mathrm{c}}$, Allen Chen ${ }^{\mathrm{b}}$, C.-S. Liu ${ }^{\mathrm{d}}$ \\ anstitute for Geophysics, Jackson School of Geosciences, The University of Texas at Austin, 4412 Spicewood Springs Rd., Bldg. 600, \\ Austin, TX 78759-8500, USA \\ ${ }^{\mathrm{b}}$ National Taiwan Ocean University, Institute of Applied Geophysics, Keelung, Taiwan \\ ${ }^{\mathrm{c}}$ Institute of Seismology, National Chung Cheng University, Chiayi, Taiwan \\ ${ }^{\mathrm{d}}$ Institute of Oceanography, National Taiwan University, Taipei, Taiwan
}

Received 14 January 2004; accepted 28 February 2005

Available online 13 April 2005

\begin{abstract}
We have used combined onshore and offshore wide-angle seismic data sets to model the velocity structure of the Taiwan arc-continent collision along three cross-island transects. Although Taiwan is well known as a collisional orogen, relatively few data have been collected that reveal the deeper structure resulting from this lithospheric-scale process. Our southern transect crosses the Hengchun Peninsula of southernmost Taiwan and demonstrates characteristics of incipient collision. Here, 11-kmthick, transitional crust of the Eurasian plate (EUP) subducts beneath a large, rapidly growing accretionary prism. This prism also overrides the N. Luzon forearc to the east as it grows. Just west of the arc axis there is an abrupt discontinuity in the forearc velocity structure. Because this break is accompanied by intense seismicity, we interpret that the forearc block is being detached from the N. Luzon arc and Philippine Sea plate (PSP) at this point. Our middle transect illustrates the structure of the developing collision. Steep and overturned velocity contours indicate probable large-scale thrust boundaries across the orogen. The leading edge of the coherent PSP appears to extend to beneath the east coast of Taiwan. Deformation of the PSP is largely limited to the remnant N. Luzon arc with no evidence of crustal thickening to the east in the Huatung basin. Our northern transect illustrates slab-continent collision - the continuing collision of the PSP and EUP as the PSP subducts. The collisional contact is below $\sim 20 \mathrm{~km}$ depths along this transect NE of Hualien. This transect shows elements of the transition from arc-continent collision to Ryukyu arc subduction. Both of our models across the Central Range suggest that the Paleozoic to Mesozoic basement rocks there may have been emplaced as thick, coherent thrust sheets. This suggests a process of partial continental subduction followed by intra-crustal detachment and buoyancy-aided exhumation. Although our models provide previously unknown structural information about the Taiwan orogen, our data do not define the deepest orogenic structure nor the structure of
\end{abstract}

\footnotetext{
* Corresponding author. Tel.: +1 512471 0480; fax: +1 5124710348.

E-mail address: kirk@ig.utexas.edu (K. McIntosh).
} 
western Taiwan. Additional seismic (active and passive), geologic, and geodynamic modeling work must be done to fully define the structure, the active deformation zones, and the key geodynamic process of the Taiwan arc-continent collision.

(c) 2005 Elsevier B.V. All rights reserved.

Keywords: Taiwan; Arc-continent collision; Crustal structure; Seismic reflection; Seismic refraction; Tomography; Continental subduction

\section{Introduction}

Arc-continent collision is a tectonic process that has played an important role in the evolution of the Earth. It is one of the primary tectonic environments for large-scale mountain building, island arc accretion to continental margins is one of the most commonly cited mechanisms for the growth of continental crust, and it is a typical environment for the poorly known process of continental subduction. As one of the few places in the world experiencing arc-continent collision, Taiwan has been used as a natural laboratory by many investigators to study collision-related processes. Chai (1972) was among the first to recognize that the Taiwan orogen is the result of the collision of the North Luzon arc with the Chinese continental margin (Fig. 1). Suppe $(1980,1981)$ elucidated the oblique nature of the collision, quantified its expected southwestward propagation, and estimated collisionrelated shortening of the continental margin at 160 $200 \mathrm{~km}$. Suppe (1987) also investigated the overall shape of the fold and thrust belt and proposed to explain the orogenic processes as a doubly vergent accretionary wedge, with the Philippine Sea plate acting as a westward-dipping backstop. While most early work focused on mountain building related to collision, Teng (1996) interpreted post-orogenic extensional collapse in northeastern Taiwan and the southwesternmost Okinawa trough-Ryukyu arc areas due to progressive southwestward subduction polarity flipping, i.e., the change from collision with the Philippine Sea plate (PSP) overriding the Eurasia plate (EUP) to that of PSP subduction as along the Ryukyu arc northeast of Taiwan. Teng et al. (2000) further proposed that the interpreted subduction polarity flip is due to EUP slab break-off, a consequence of collision and continental subduction that has been predicted by several studies (Davies and von Blanckenburg, 1995; Hildebrand and Bowring, 1999). Exploring a different approach to mountain building in Taiwan, Wu et al. (1997) proposed a lithospheric collision model rather than the more thinskinned type of model proposed by Suppe (e.g., 1987). On the basis of an expanded catalog of earthquake data for Taiwan, they noted thickened continental crust beneath Taiwan and assorted deep seismic zones, which suggest collision-related deformation within the entire crust and into the upper mantle. Chemenda et al. (1997) used analog modeling techniques to investigate arc-continent collision based on the configuration in Taiwan. A key prediction of this work is the likely separation of the forearc block from the PSP and its subsequent rotation (about a horizontal axis) or subduction. Lallemand et al. (2001) used regional seismic tomography to show the approximate positions of the EUP and PSP slabs and how they may interact beneath northeast Taiwan. Using the interpreted position of these slabs and constraints from regional geology, they also developed a Late Neogene plate reconstruction, which features initial Luzon arc collision with the continental margin at $126^{\circ} \mathrm{E}$ and subsequent westward collision propagation along a regional tear fault now marking the southern limit of Ryukyu forearc basement. Sibuet and Hsu (2004) proposed a fairly similar scenario of collision development and associated Okinawa trough opening with westward passage of the colliding Luzon arc. In addition they suggested that the upper portions of the Luzon arc may have been accreted to what is now the Ryukyu forearc. Malavieille et al. (2002) investigated the development of arc-continent collision by studying the different stages of the Taiwan collision from south to north. Although their models are constrained only at shallow levels by onland geologic studies and by marine geological and geophysical data from surrounding areas, they interpret several deep crustal processes, including forearc detachment, as in Chemenda et al. (1997), accretion of continental crustal material, and continental subduction.

The interpretations noted above illustrate a general evolution of understanding in arc-continent 

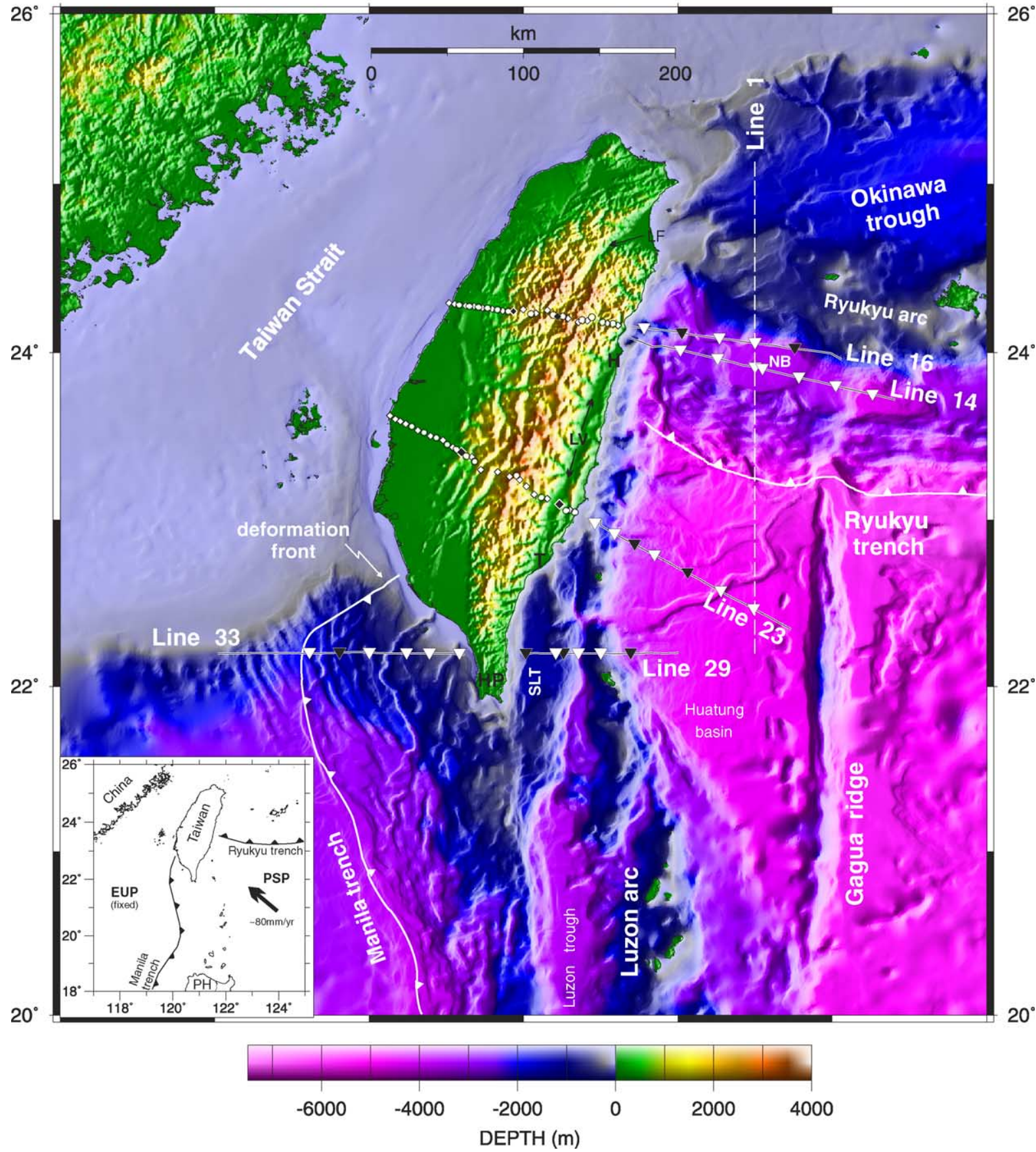

Fig. 1. Map of Taiwan and vicinity showing elevation onshore and bathymetry in offshore areas and locations of seismic transects (EW9509-) $29 / 33,23,14$, and 16. In addition, Line 1 is marked as a white dashed line because it is referred to but not analyzed in this paper. Lines in the offshore mark MCS acquisition, while triangles along these lines show OBS locations. Land seismic stations are marked by the diamond symbols (Reftek) and circle symbols (K2), which cross Taiwan in two linear patterns. For both OBS and land stations, the black-filled symbols mark stations whose records are shown in subsequent figures. $\mathrm{H}=$ Hualien; $\mathrm{T}=$ Taitung; $\mathrm{HP}=$ Hengchun Peninsula; $\mathrm{NB}=\mathrm{Nanao}$ basin; $\mathrm{LV}=$ Longitudinal Valley. Bathymetry described in Liu et al. (1998). 
collision processes, especially with regard to Taiwan. However, despite the advances that have been made on the basis of surface geology, marine studies, upper-crustal geophysical studies, and modeling, there is still great uncertainty about the deeper structure and orogenic processes because of the lack of lithospheric-scale data and limited crustal-scale information. Truly fundamental questions remain, including the following: To what extent has continental subduction occurred beneath Taiwan? If significant continental subduction has occurred, how has that affected the structure and mountain building processes? If the collision is lithospheric in scale, does the crust of both the PSP and EUP deform and thicken? How does the collision develop from the initial condition of oceanic subduction to full arc-continent collision? How does arc-continent collision in Taiwan evolve through time? In this paper we describe results of combined onshore/ offshore seismic data sets recorded during the 1995 TAICRUST survey, a joint Taiwan-United States geophysical project, which resolve deeper parts of the Taiwan orogen, especially from the eastern Central Range to the PSP, and provide clues about the evolution of arc-continent collision in Taiwan. These data have previously been analyzed in relative isolation, i.e., onshore only, offshore only, or by single offshore transect. The combined analysis of three transects, from southernmost Taiwan to the northern Cross Island highway, now provide critical geophysical constraints, at crustal to near-crustal scale, which we can use to test and modify the numerous published models. Following a further description of the tectonic environment and previous work, we describe the TAICRUST survey and resulting data sets we use. We then discuss the three transects, from south to north, showing specific data examples, models of the velocity structure, and a first-order interpretation of the velocity structure. Finally, we discuss the significance of our results and compare them to existing interpretations.

\section{Geologic and tectonic setting}

Taiwan is the site of active arc-continent collision that started when the North Luzon arc, along the western edge of the Philippine Sea plate (PSP), encroached upon the passive Chinese continental margin. Before the collision the plate configuration was probably similar to the present-day situation south and west of Taiwan (Chai, 1972; Suppe, 1981). Here the Eurasian plate (EUP) is characterized by a rifted, passive continental margin, a zone of transitional crust/lithosphere, and, farther southeast, oceanic crust (Bowin et al., 1978; Taylor and Hayes, 1983). Alternatively, as proposed by Sibuet et al. (2002), a southwest extension of the Ryukyu arc may have been present in Taiwan's current position prior to Middle Miocene time but abandoned in a plate reorganization before collision. The Philippine Sea plate overrides the oceanic crust of the Eurasia plate as it moves to the northwest at $\sim 81 \mathrm{~mm} /$ year (Yu et al., 1997, 1999), and its western margin is characterized by the North Luzon volcanic arc, the North Luzon trough forearc basin, and a northward expanding accretionary prism (Bowin et al., 1978; Taylor and Hayes, 1983; Lundberg et al., 1997). Although the tectonic environment of Taiwan is shaped by only two converging plates, it is greatly complicated by the change in subduction polarity that occurs in the vicinity of Taiwan. Here the PSP changes drastically from subducting along the Ryukyu arc-trench system to the northeast to colliding with and overriding the EUP to the south and southwest (Chai, 1972; Angelier, 1986; Sibuet et al., 2002).

Because of its unique and very active tectonic environment, the onshore geology of Taiwan has been well studied. The basic structural and lithologic units are parallel to the island's NNE-SSW trend and nearly perpendicular to the direction of plate convergence. From west to east (Fig. 2) the tectonostratigraphic units include the coastal plain, Western Foothills, the Hsuehshan Range, the Central Range (including the Backbone Range and eastern Central Range), and the Coastal Range (Chai, 1972; Teng, 1990). Within this arrangement, the coastal range has its origin in the allochthonous North Luzon volcanic arc, part of the PSP, while all other units to the west, including the slates, schists, and higher-grade metamorphic rocks of the Central Range, are considered to be derived from the Chinese continental margin (Chai, 1972; Ho, 1986). The fold and thrust belt of the western foothills has been a fertile study area for developing quantitative 


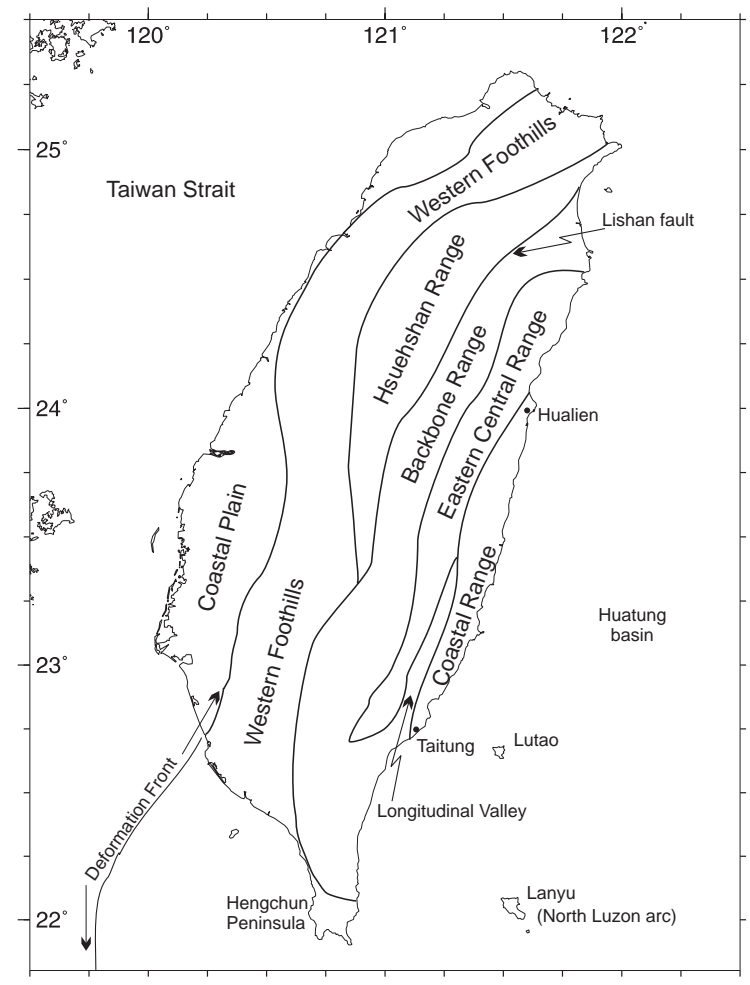

Fig. 2. Simplified map showing the major tectonostratigraphic belts of Taiwan (Ho, 1986) and geographical locations referred to in the text. The Hsuehshan and Backbone ranges are collectively considered the slate belt. Morphologically, the Central Range includes the Backbone Range and the higher-grade Paleozoic to Mesozoic metamorphic rocks of the eastern Central Range.

geologic cross-section techniques (Suppe and Namson, 1979; Suppe, 1981, 1987).

\section{Data acquisition and processing}

The TAICRUST experiment took place in August and September 1995, and it included five transects with simultaneous multichannel seismic reflection (MCS) and ocean bottom seismograph (OBS) data acquisition. In this paper we describe results from three of these transects, including two which also had large-scale onshore instrument deployments and one transect which had a smaller onshore deployment across the narrow Hengchun Peninsula. In this project OBS instruments from National Taiwan Ocean University (NTOU) and the University of Texas at Austin Institute for Geophysics (UTIG) were deployed and recovered from the R/V Ocean Researcher I while airgun source firing and MCS acquisition were performed with the R/V Maurice Ewing. No additional land sources were used and data recorded by the land stations were exclusively from the airgun shots fired in the eastern offshore areas of Taiwan (Fig. 1). The nominal airgun source interval was $100 \mathrm{~m}$ for lines EW9509-16 and EW9509-23 (called Lines 16 and 23 hereafter), with time between shots of $40 \mathrm{~s}$. On line EW9509-29/33 (Line 29/33 hereafter) the source interval was nominally $50 \mathrm{~m}$, with time between shots $20 \mathrm{~s}$. The MCS trace spacing was $25 \mathrm{~m}$, with 160 channels and a far offset of $\sim 4200 \mathrm{~m}$. The source array was composed of 20 airguns with a total volume of about $1381\left(8400\right.$ in $\left.^{3}\right)$.

All the OBSs recorded three geophone channels, two horizontal and one vertical component, and most (>than $80 \%$ ) of the deployments also recorded signals from a hydrophone. The OBS spacing varied from $\sim 15-25 \mathrm{~km}$ along the three transects. The OBS sample interval was $4 \mathrm{~ms}$ and recording alias filters were set at $30 \mathrm{~Hz}$ and $50 \mathrm{~Hz}$ for the geophones and hydrophone, respectively. Source navigation was provided by continuous GPS coverage, and simultaneous GPS recording at a land station allowed for post cruise differential GPS (DGPS) navigation processing. This DGPS navigation data set was then used to relocate and orient the OBSs based on water wave arrivals.

The land seismic stations used in our modeling included both Reftek instruments supplied by the PASSCAL instrument center and K2 instruments supplied by the Institute of Earth Sciences at Taiwan's Academia Sinica. Both of these sets of instruments recorded continuously during airgun shooting (Hetland and Wu, 1998; Yeh et al., 1998). The locations and time base for these instruments were acquired from GPS receivers. Similar to initial OBS processing, a "shotfile" containing the ship's position and timing of airgun shots was used to calculate shot receiver ranges and convert the seismic data to SEG-Y format.

The MCS data processing was performed largely at the University of Hawaii and at National Taiwan University. In general, standard techniques were used including trace editing, deconvolution, sort to common midpoint gathers, normal moveout velocity analysis and correction, stack, band-pass filtering, and time migration (Liu et al., 1997). In addition, many other techniques were used to reduce multiple 
reflections or other noise as needed. A description of those processing steps, including $\mathrm{f}-\mathrm{k}$ and Radon filtering, dip-moveout (DMO), and wave equation multiple suppression is given by Berndt and Moore (1999). We note that not all of these steps were applied to all data, and multiple reflections still contaminate much of the MCS data presented in this paper. Initial OBS processing includes instrument relocation and orientation, clock-drift correction, trace rotation (to transverse and radial directions), and data reformatting to SEG-Y. The OBS and land data processing was relatively simple and typically included band-pass frequency filtering and some form of gain, such as gain increasing with distance or time or amplitude balancing with a sliding window automatic gain control (AGC). We also used trace mixing (3 to 5 traces), deconvolution, and spectral balancing, especially in the presence of high amplitude, narrow-band, reverberative noise as needed to increase signal to noise ratio.

\section{Analysis and results}

\subsection{Modeling techniques}

To interpret the wide-angle seismic data sets in this study we used the travel-time inversion package RAYINVR (Zelt and Smith, 1992) and the firstarrival travel-time tomography code FAST (Zelt and Barton, 1998). We created the RAYINVR models first, assuming typical velocity profiles for oceanic crust, arc terranes, and continental margins and then performing forward modeling and inversion to get a layered velocity model. Subsequently we used the RAYINVR results to build 1-D starting models for the tomographic inversions. This process involved determining an average velocity structure from the existing model and registering this function to the seafloor. In the case of the land areas, we developed a velocity model based on the initial interpretations by Hetland and Wu (1998) and Shih et al. (1998), in which the primary difference from the offshore areas is a thicker crustal section. We tested a suite of somewhat different 1-D models in the inversions and found the results to be quite similar. Thus primary features of the final models do not appear to be inherently dependent on details of the starting model.
The structure in the study area is complicated, especially along the onshore/offshore transects, so the tomography code, with 1-D starting models, provides a way to model the first-arrival travel-times without adding potential bias in the process of parameterizing a layer-based model. Because FAST is designed to give the minimum structure model that is required by the data (Zelt and Barton, 1998), we consider the results robust where the models are well resolved, but key structural features may be poorly determined in areas of poor ray coverage or large instrument spacing. For the inversions we used $\sim 19,670$ picks on the three transects (24 OBS and 25 land station records). These were the result of decimation or interpolation of the original picks to provide fairly even coverage at $125-250 \mathrm{~m}$ spacing in OBS data and 200-400 m pick spacing for the land data. The picking uncertainty increases substantially with distance, with the uncertainty range 50$140 \mathrm{~ms}$ for Line 29/33 and 60-240 ms for Lines 23 and 16 . These uncertainty values were adjusted for the inversion to achieve a $\chi^{2} \approx 1$ and are slightly larger than the actual picking uncertainty to accommodate actual arrival time scatter produced by short wavelength structural irregularities. We checked the OBS data sets for consistent reciprocal arrivals, while the land stations could only be checked qualitatively for similar patterns on nearby stations.

\subsection{Tomography resolution tests}

We used a procedure similar to that described by Zelt (1998) to analyze resolution of our first arrival tomographic inversions. Briefly stated, we took the following steps: (1) Generate checkerboard patterns and apply them to perturb the velocity model derived by tomographic inversion. The horizontal dimension of each cell was $10,20,40$, or $80 \mathrm{~km}$, and the vertical dimension of each cell was set to $1 / 4$ of the horizontal dimension to account for the fact that most rays are directed more horizontally than vertically. For each cell size, eight different cell patterns were generated. The maximum velocity perturbation was $\pm 5 \%$. The velocity in the water column was not perturbed. (2) For each cell size and each checkerboard pattern, compute theoretical firstarrival travel-times of the perturbed models. (3) Add random noise to the calculated picks such that the 
variance of the noise was set equal to that assigned to the original arrival time readings. (4) Perform tomographic inversion of the perturbed and noiseadded theoretical arrival times to generate a new velocity model. (5) Subtract the velocity values of the original model from those of the newly generated velocity model to recover the checkerboard pattern. (6) Compute the semblance between the original and the recovered checkerboard patterns to estimate resolvability for each pattern. (7) For each cell size, the resolvabilities of all eight patterns are averaged to obtain an estimate of resolvability for the cell size.

(8) Compute estimated resolution from the resolvabilities for different cell sizes. Cosine-bell weighting functions of length equal to the cell size were used for smoothing of the resolvability data. This is somewhat different from the original Zelt (1998) procedure, where a boxcar weighting function of fixed length was used.

Because the resolution testing generated a large number of additional figures, we have chosen to display the results directly on the velocity models. In model figures that follow, the heavy, dashedyellow line marks the portion of the models (i.e., above the line) where features $40-80 \mathrm{~km}$ in horizontal dimension are resolved. Thus, this is about the maximum depth that can be reasonably interpreted for large-scale structure. The resolution progressively improves at shallower levels to a limit of about $20 \mathrm{~km}$ in horizontal dimension, due to the relatively coarse instrument spacing. As an additional guide we also include displays of observed (black) and calculated (orange) travel-time picks below each velocity model figure. These are displayed without reduction velocity to allow greater separation between records. Due to the display size, the calculated times are largely covered by the observed times, so the orange is primarily visible where misfit is greater than $\sim 100 \mathrm{~ms}$.

\subsection{Hengchun Peninsula transect: incipient collision}

The southern tip of Taiwan, the Hengchun Peninsula, protrudes southward beyond the trend of the continental margin (Fig. 1) and is expected therefore to be primarily a sedimentary accretionary complex (Nakamura et al., 1998). To the east of the peninsula the Huatung ridge has been built from deformed material of the N. Luzon trough forearc basin, and now extends close to the now-inactive portion of the N. Luzon arc. The composite Line 29-33 provides data to help describe the tectonic environment of incipient collision.

\subsubsection{Line 29/33 MCS data}

Line 33 shows the incised slope of the Chinese continental margin, the thickly sedimented deformation front area, the rapidly growing accretionary prism, an a non-reflective body just west of the Hengchun Peninsula (Fig. 3, part 1). Although the water-bottom multiple reflection obscures much of the section close to the Hengchun Peninsula, it is clear near the trench that strata to 3-s two-way time, or 3-4 km depth, are folded into a series of anticlines. Thus it appears that most of the sedimentary section present at the deformation front is incorporated into the accretionary wedge. The lack of reflections in the zone at the east end of Line 33 is somewhat puzzling; there seems to be no evidence of the large folds that have developed on the adjacent trench slope to the west. We suggest that stratal dips may be very steep in this section, or perhaps the original bedding is largely dismembered at this state of advanced deformation. Structural fabric, such as fault planes and foliation planes, may be present in this zone but could also dip too steeply for reflection imaging. This interpretation is also supported by OBS modeling results, which showed anisotropic variations in travel-times through this zone depending on direction and angle (Nakamura et al., 1998). In addition to these processes other factors which may lead to this poorly reflective seismic character are ancient or active diapirs, many of which have been identified southwest of Taiwan (Liu et al., 1997), and carbonate buildups, which are known from the onshore Hengchun Peninsula (Chang et al., 2003).

East of the Hengchun Peninsula, Line 29 shows deformed strata beneath the southern longitudinal trough (SLT), the uplifted Huatung ridge, the remnant N. Luzon arc, and the westernmost Huatung basin (Fig. 3, part 2). The structure beneath the SLT indicates eastward vergent thrusting, and we interpret the Huatung ridge to be a composite compressional structure, which has been thrust eastward approaching the arc. Structures within the arc complex are poorly resolved, but a stratigraphic layering becomes more apparent on the eastern flank. The eastern limit of the 


\section{Part 1}

$12000 \quad 10000$

8000 Trace Number 6000

4000

2000

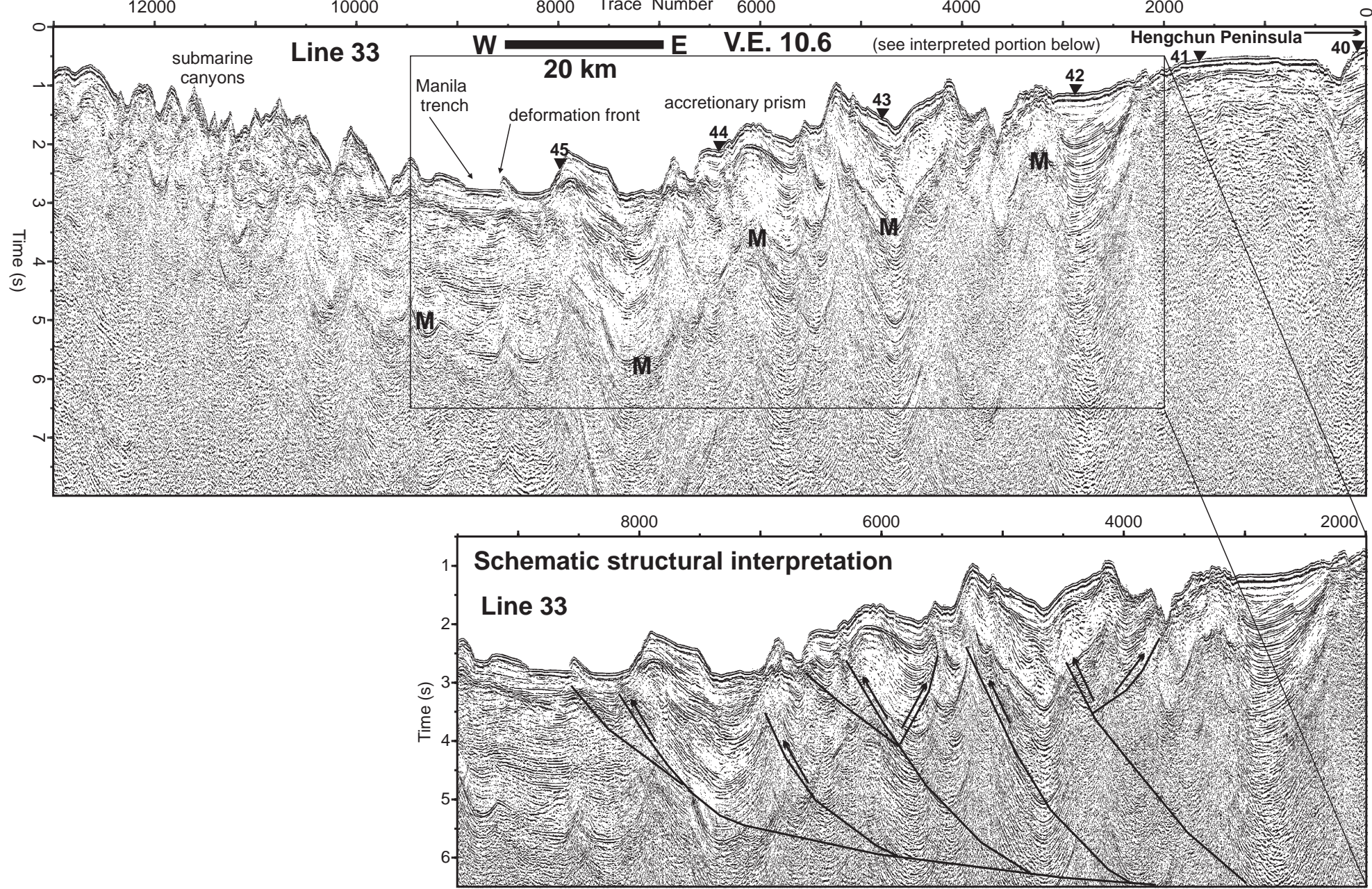




\section{Part 2}

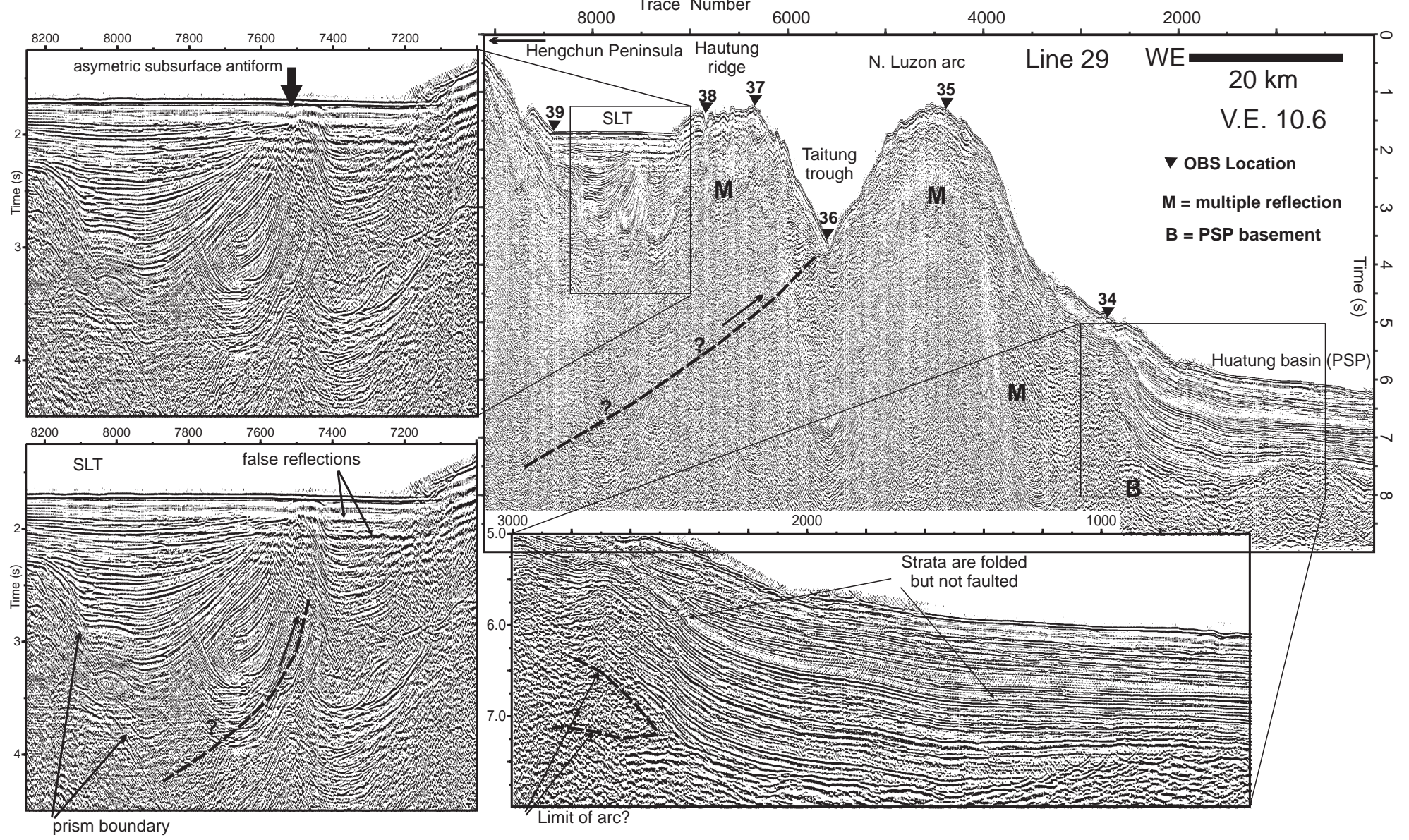

Fig. 3. Seismic reflection sections of Lines 33 (west; part 1) and 29 (east; part 2) on both sides of the Hengchun Peninsula of southernmost Taiwan. In part 1, Line 33 shows the continental slope, dissected by submarine canyons, the Manila trench, and the rapidly growing accretionary wedge. The box in the upper panel marks the portion of Line 33 included in the lower panel with a schematic structural interpretation of the growing accretionary prism. In part 2, Line 29 shows early-stage collisional structures of the southern longitudinal trough (SLT), Huatung ridge, and Taitung trough as they encroach upon the N. Luzon arc. Insets at left show close-ups of east-vergent thrust structure in the subsurface SLT, including approximate thrust fault location below the antiform. False reflections, probably airgun bubble-pulse reverberations, are indicated. Inset below-right shows close-up of folded but largely unfaulted strata at the eastern margin of the N. Luzon arc. OBS positions are marked by black triangles and labeled 34-45; B=PSP top-basement reflection at probable edge of the arc; M=water bottom multiple reflection. 
arc terrane is quite abrupt and is marked by the relatively thick sedimentary section. Although some investigators interpret that the arc terrane is being thrust eastward over the converging PSP at this latitude and particularly to the north (Malavieille et al., 2002), we observe that the stratal reflections from the east flank of the arc and into the basin seem to be very continuous. The only suggestion of deformation here is the relatively steep dip of the strata at the east flank of the arc (Fig. 3, below OBS 34), which diverges from a nearly flat-dipping basement reflection below. However, arc volcanics may well have flowed over the PSP crust to create this reflection pattern along with normal deep sea sediment draping. Note that the reflection image is highly exaggerated $(\sim 10: 1$ at the seafloor) to make stratigraphic features visible.

\subsubsection{Line 29/33 OBS data examples}

Wide-angle seismic data were recorded along Line 29/33 simultaneously with the MCS acquisition. These data were recorded on 12 OBSs deployed on both sides of the Hengchun Peninsula (Fig. 1) and provide good coverage of the accretionary prism. Fig. 4 shows four examples of wide-angle seismic data recorded along this transect. OBS 44 shows refracted arrivals from the accretionary wedge, reflections from the top of the subducting EUP crust, and refractions from within this transitional crust. The OBS 39 record shows arrivals to $200 \mathrm{~km}$ offset, including Pn, which turned in the upper mantle of the subducting EUP. OBSs 37 and 34, from east of the peninsula, both provide good evidence for a thick zone of relatively low velocity material between the arc and the peninsula. Apparent velocity across the shallow portion of the SLT is $\sim 2.3 \mathrm{~km} / \mathrm{s}$ on OBS 37 and OBS 34 has a discontinuous first-arrival, delayed by $>1 \mathrm{~s}$ (at $8 \mathrm{~km} / \mathrm{s}$ reduction velocity) beneath the SLT (Fig. 4).

\subsubsection{Line 29/33 model description, observations, and interpretation}

The FAST tomographic travel-time inversion for the Line 29/33 transect across the Hengchun pen- insula produced a velocity model relatively similar to the previous work, but has perhaps better defined some of the critical features. The result is shown in Fig. 5 where the upper figure shows the velocity model and OBS locations, the middle figure shows the same velocity model with a simplified tectonic interpretation and labels for the main tectonic elements $(\mathrm{M}=$ Moho, $\mathrm{D}=$ decollement, $\mathrm{SLT}=$ southern longitudinal trough, NLA=North Luzon arc), and the lower model figure has a 20-km-wide swath of seismicity, from Taiwan's Central Weather Bureau (1994-2002) superimposed on the velocity model. The bottom panel shows observed (black) and calculated (orange) travel-times for all the instruments. The green dashed line labeled M shows the approximate Eurasian plate Moho position; this boundary is well constrained only in the model range $\sim 70-115 \mathrm{~km}$, but is consistent with the results of Nakamura et al. (1998), who estimated basement crustal thickness of $\sim 11 \mathrm{~km}$ in this subducting transitional crust. From the coincident MCS profiles and the velocity model we estimate the position of the subduction thrust boundary (decollement) as shown with the dashed white line labeled D. West of the Hengchun Peninsula we expect the decollement to remain within the sedimentary section above the 5 $\mathrm{km} / \mathrm{s}$ velocity contour. From Hengchun Peninsula to the east the slab is not resolved with the OBS data. However, the earthquake hypocenters define a band of events over this region, which is consistent with the interpreted plate boundary and shows the slab position to $150 \mathrm{~km}$ depth.

The relatively high-velocity core beneath Hengchun Peninsula appears to extend down to the decollement. This is older, possibly metamorphosed accretionary prism material, accreted basement material from the subducting transitional crust, or possibly both. The eastward verging thrust system overriding the forearc basement block is based on MCS images along this profile (Fig. 3), well imaged thrusting observed in several data sets to the south (e.g., Lundberg et al., 1997), and there is a

Fig. 4. Examples of OBS data used for tomography. Instruments were stationed on both sides of the Hengchun Peninsula and recorded airgun shots from both sides. OBS 44 arrivals sampled the accretionary wedge (Pw) and the subducting plate (Ptc), while OBS 39 shows clear arrivals, which turned in mantle of the subducting EUP (Pn). Arrivals recorded by OBSs 37 and 34, located east of the Hengchun Peninsula, show the effects of the elevated N. Luzon arc (NLA) and the contrasting low velocity material between the arc and the peninsula. The arrow on the OBS 34 record section points to the delayed first arrival. 

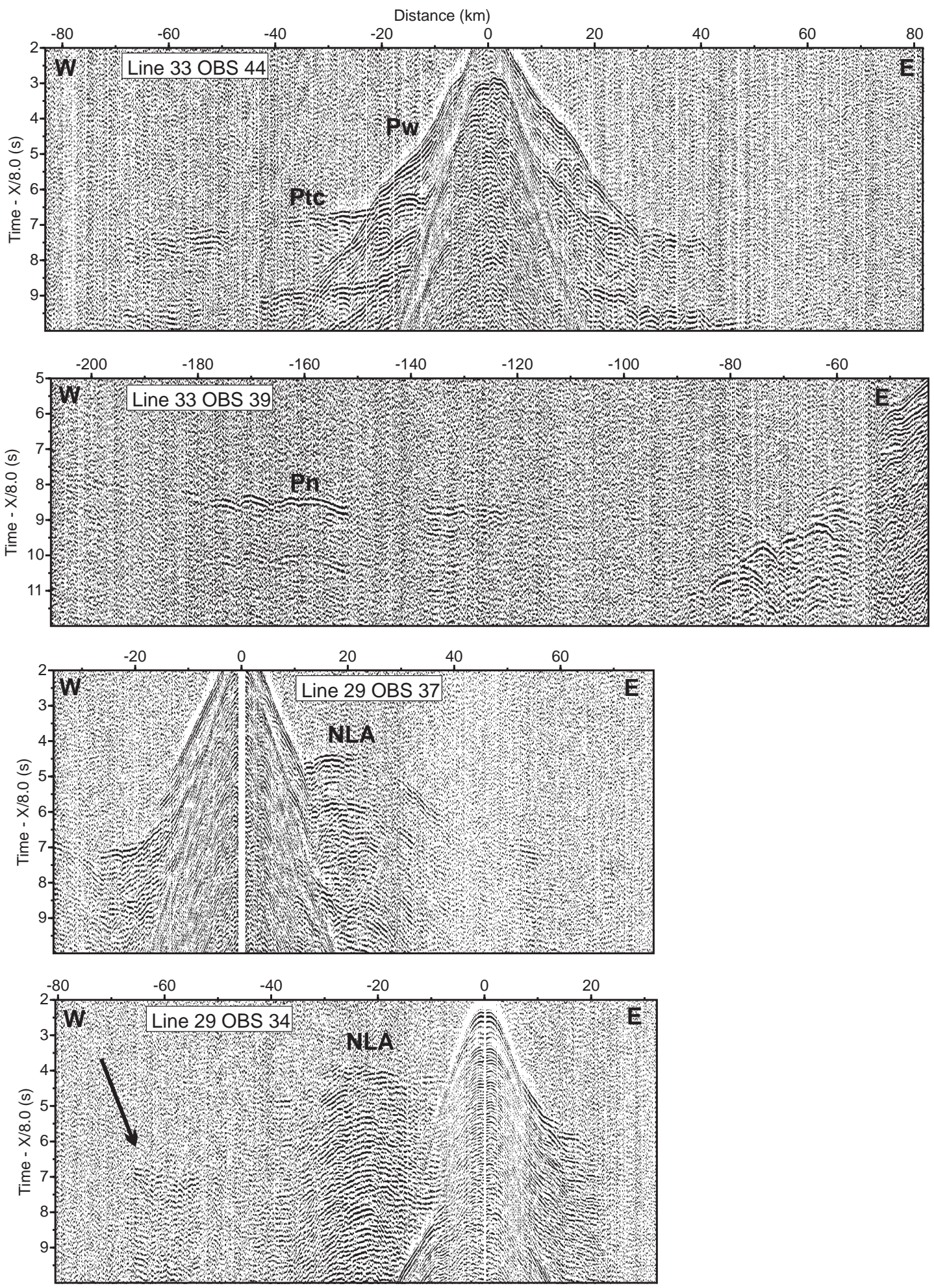
concentration of earthquakes near the top of the forearc basement, as roughly defined by the $6 \mathrm{~km} / \mathrm{s}$ contour. This contour extends beneath the SLT and Hengchun Peninsula, dipping gently westward, but at model offset $\sim 170 \mathrm{~km}$, this contour reverses dip. While we interpret the westward-dipping limb as the top of the forearc basement, the eastward-dipping limb marks the subducting basement of the EUP. Both observational data (Biju-Duval et al., 1982; Westbrook, 1982) and modeling (Byrne, 1993) suggest that the thickest part of an accretionary prism will develop above the intersection of a trenchward-dipping forearc block and the subducting plate, so it is appropriate that the change in basement dip polarity, i.e., the basement plate boundary intersection, occurs beneath the Hengchun Peninsula.

Perhaps the most important result from this model is the abrupt velocity change (see $5 \mathrm{~km} / \mathrm{s}$ contour) near model offset $240 \mathrm{~km}$. Although we do not directly know the original structure of the arc flank, the vertical to overturned velocity contours suggest that the forearc block is detached from the N. Luzon arc. Furthermore, earthquake activity shown in the lower panel of Fig. 5 strongly supports this interpretation, with a very concentrated band of events delineating a steeply east-dipping fault zone coincident with the offset in the velocity model. Focal mechanisms associated with this seismically active zone indicate north-south to northeast striking thrust faults (Kao et al., 2000). These primary observations tend to support some form of the collision model proposed by Chemenda et al. (1997, 2001), which assumes that the arc is a zone of weakness and is thus the likely location for separation with the forearc block.

\subsection{Southeast Taiwan/huatung basin transect: full collision}

At the latitude of $23-23.5^{\circ}$ all aspects of the arc continent collision are in place. The N. Luzon arc is accreted as the Coastal Range, the pre-Tertiary basement of the former passive margin is uplifted and exposed in the Central range, and both Paleogene and Neogene strata make up the mountains of central and western Taiwan. The Line 23 transect provides geophysical characteristics of the collision.

\subsubsection{MCS data Line 23}

Line 23 MCS data extends offshore eastern Taiwan (Fig. 1) from the flank of the remnant N. Luzon arc, across the continental slope, and across the Huatung basin (PSP). Full collision is taking place along the onshore continuation of this transect, so we can examine this offshore portion to see if there is significant collision-related deformation of the PSP. There is a consistent wavy pattern in the shallow sedimentary section (Fig. 6), up to the seafloor, from east of OBS 29 to the Taitung canyon, but these features do not seem to extend deep into the section and are likely due to gravity sliding into the Huatung basin. The well-developed sedimentary section generally thickens westward and reflections are fairly continuous until the base of the steep slope section. Here, between OBSs 28 and 29, dips become steep and the seafloor is rough. Just landward of OBS 28 there is a major scarp at the seafloor and reflections in the subsurface show large folds with a wavelength $>5 \mathrm{~km}$. This zone may mark the eastern limit of significant collision related deformation. The only other possible collision related deformation farther east appears to be the basement offset and fold in the deep sedimentary section below and just east of OBS 30. Alternatively, this may mark the edge of the arc edifice and be unrelated to the collision. On the basis of this MCS profile, significant collisional deformation seems to be limited to the areas west of OBS 29.

\subsection{2. $O B S$ and land data examples Line 23}

Wide-angle seismic data were recorded by both OBSs and an array of seismographs extending across the island of Taiwan. Airgun shots from east of Taiwan were well-recorded in the mountainous portions of the transect, but, due to a combination of distance, cultural noise, and probable higher attenuation in the young foreland sedimentary section, these shots were not recorded in the coastal plain of western Taiwan. Airgun shots from west of Taiwan were not recorded by this instrument array. Thus our data set and model for this transect extend from the western foothills of Taiwan to near the Gagua ridge on the PSP. Here we present four key record sections (Fig. 7) to indicate the type of data used in the modeling. The upper section was recorded at station 214 (Fig. 1, black-filled diamond) in the Western Foothills $\sim 110$ 

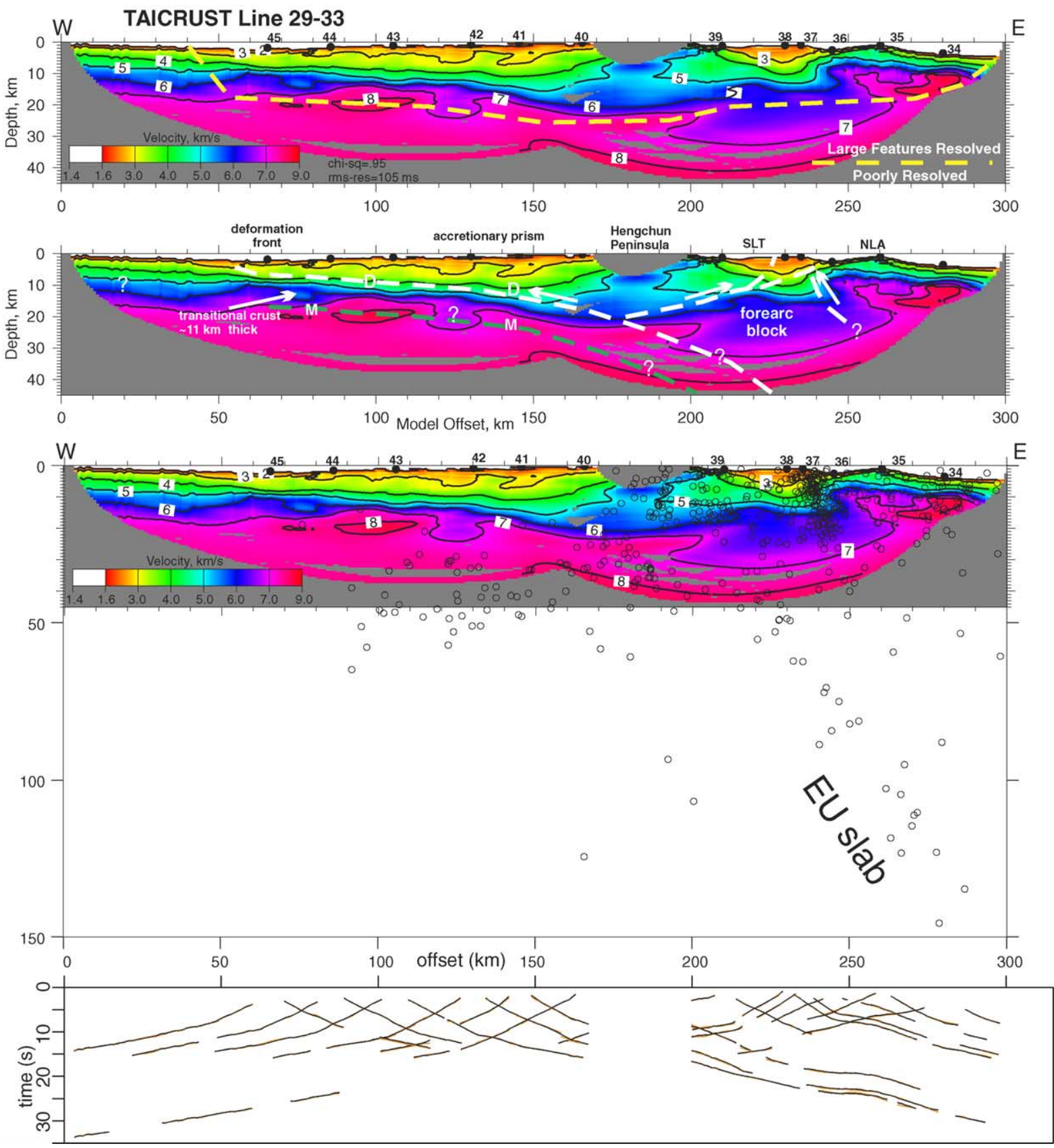

Fig. 5. Tomographic velocity model of the Line 29-33 transect. The top panel shows the velocity model, instrument locations, and the dashed yellow line marks the limit of good model resolution. The curving edges of the colored model show the limits of the rays traced during the inversion. The center panel shows a first-order interpretation of the model, using additional constraints from seismicity and surface morphology. The basal detachment between the accretionary wedge and subducting transitional crust is labeled $\mathrm{D}$, and the base of this crust is labeled M. The lower model panel includes earthquakes recorded by the Taiwan CWB network during 1994-2002 (20 km swath width). The bottom panel shows observed (black) and calculated (orange) travel-times for all the instruments. 


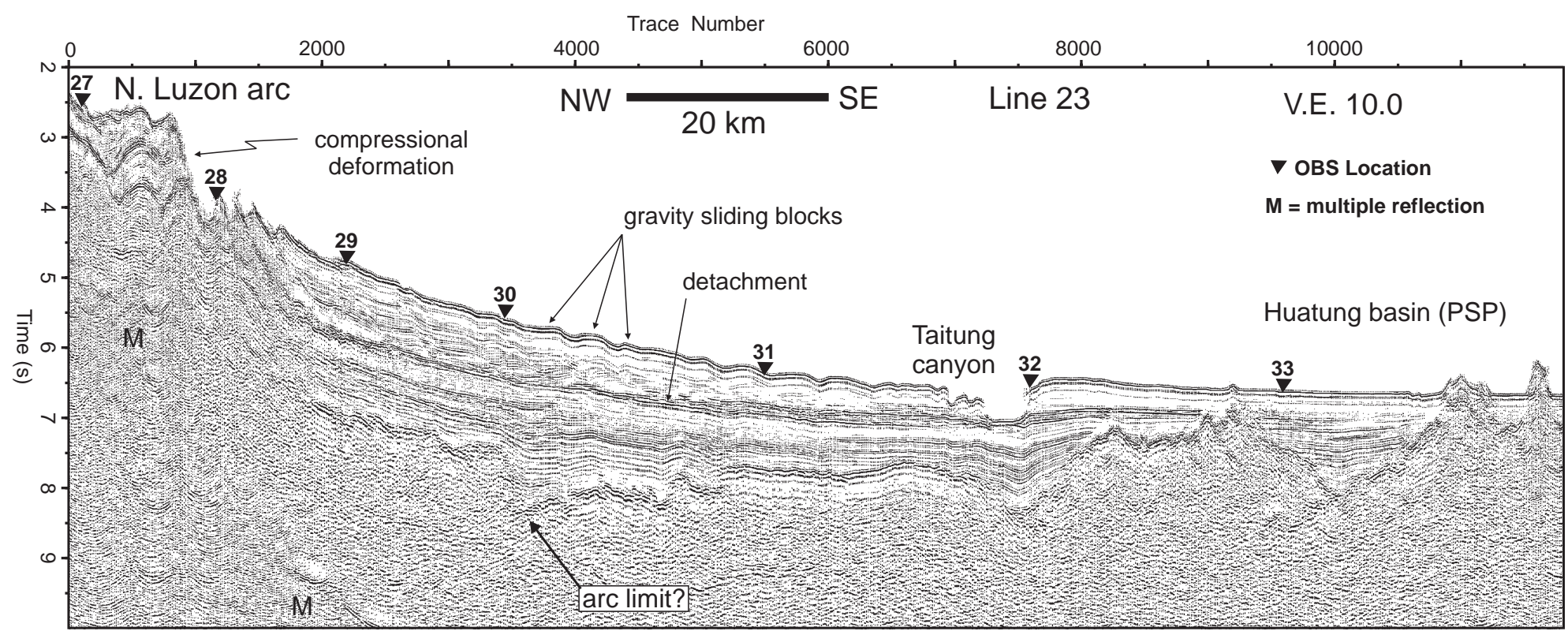

Fig. 6. Line 23 MCS data offshore southeastern Taiwan from the accreted N. Luzon arc into the Huatung basin of the PSP. OBS positions are marked with triangles and labeled. Multiple reflections (to be disregarded) are marked with M. This section is vertically exaggerated (10:1 at the seafloor) to reveal the stratigraphy. Some very limited thrust faulting is possibly suggested beneath OBS 30 in the lower half of the sedimentary section, but the large folds between OBSs 27 and 28 indicate that compressional deformation is focused farther upslope. Shallow deformation on the lower slope to the Taitung canyon appears to be gravity sliding above a seismically bright and smooth detachment near the middle of the sedimentary section. 
$\mathrm{km}$ from the east coast. Although the raypaths between source and receiver may be complicated, this record suggests a Pn arrival at offsets greater than $165 \mathrm{~km}$ and extending to $215 \mathrm{~km}$. The second section was recorded at station 232 on the east side of the Longitudinal Valley (Fig. 1, black-filled diamond). It shows near arrivals, which propagated through the Coastal Range/N. Luzon arc crust, and more distant arrivals (offset $>90 \mathrm{~km}$ ), which turned in the upper mantle of the PSP east of the arc. The discontinuity and increased apparent velocity visible in both of these records at the far offsets are due to abruptly shallower basement and Moho at the SE end of Line 23 (Fig. 6). The lower two record sections of Fig. 7 were recorded by OBSs in the Huatung basin of the PSP, east of the N. Luzon arc. These sections are plotted with a reduction velocity of $6 \mathrm{~km} / \mathrm{s}$, so arrival segments that are nearly horizontal are arrivals through the oceanic crust, while arrivals inclined significantly above horizontal (with increasing offset) have propagated through the upper mantle. On these sections it is clear that the transition to mantle arrivals $(\mathrm{Pn})$ occurs at offsets of $25-30 \mathrm{~km}$. This crossover distance is typical for normal $\sim 6-\mathrm{km}$-thick oceanic crust and, along with the modeling discussed below, shows that crustal thickening due to the collision has not extended into the PSP beyond the N. Luzon arc.

\subsubsection{Line 23 model description, observations, and interpretation}

We display the Line 23 tomographic results (Fig. 8) in the same format as the southern transect, with the velocity model in each panel and limit of resolution in the upper panel, a simplified tectonic interpretation in the middle panel, and CWB seismicity (20-km-wide swath) superimposed in the lower model panel. The bottom panel shows observed (black) and calculated (orange) travel-times for all the instruments. As expected from the OBS records, the model shows normal to thin oceanic crust in the area SE of OBS 29, with increasing thickness to the west toward the remnant arc. The transition from oceanic to continental material appears to take place along a thrust boundary, which produces a velocity inversion with depth. This pattern is evident where higher-velocity oceanic crust and mantle are situated above lower velocity material below OBSs 27 and 28 as marked by the $7 \mathrm{~km} / \mathrm{s}$ contour. The pattern of crustal-scale thrust deformation continues westward as both the $6 \mathrm{~km} / \mathrm{s}$ and $5 \mathrm{~km} / \mathrm{s}$ contours show inverted velocity structures. The eastern flank of the Central Range is located in the model range $x=48-70 \mathrm{~km}$; it is here that exposures of the highest grade metamorphic rocks of this transect are found. The velocity model is very consistent with this as the $6 \mathrm{~km} / \mathrm{s}$ contour, representing middle to lower crustal continental rock (15-25 $\mathrm{km}$ depth), has been elevated to within $\sim 4 \mathrm{~km}$ of the surface. Farther west, at $x=30 \mathrm{~km}$, there is a rapid decrease in velocity with the $5 \mathrm{~km} / \mathrm{s}$ contour present to $>8 \mathrm{~km}$ depth. This velocity change correlates with the boundary between the Hsuehshan Range of deformed and lightly metamorphosed Paleogene sedimentary rocks and the Western Foothills, which contains deformed Oligocene and younger rocks. On the basis of the velocity structure and surface geology, we tentatively interpret several major thrust faults, which probably connect to a gently east-dipping basal detachment. The velocity inversion beneath the continental slope suggests a possible continuation of this detachment at $15-20 \mathrm{~km}$ depth.

The superimposed seismicity in the lower panel of Fig. 8 provides additional information to help interpret the velocity model. The clouds of hypocenters stretching from the foothills through the Central Range are partially a result of the 1999 Chi Chi earthquake, but overall show abundant seismic activity in the upper 10$15 \mathrm{~km}$, with more concentrated activity possibly related to major thrust faults. A particularly interesting zone of concentrated seismicity is present at the velocity inversion $(x=100 \mathrm{~km})$ below the east coast of Taiwan. The intense seismicity identifies this velocity boundary as a crustal-scale fault zone and lends additional credibility to the velocity model. From this zone there is enhanced seismicity, relative to background level, extending upward and west $(x=80-90 \mathrm{~km})$ most likely related to the Longitudinal Valley fault. Another zone of enhanced seismicity extends upward to the east. The upper part of this zone may be related to the deformation we noted in the MCS data (Fig. 8); deeper seismicity may mark another fault zone (Fig. 8) but extensive shallow faulting or folding is not visible on the MCS data.

In the Line 29/33 model discussion we noted that the N. Luzon arc appeared to be offset and possibly detached from the forearc basement block. Along the Line 23 transect it is not clear that the forearc block 

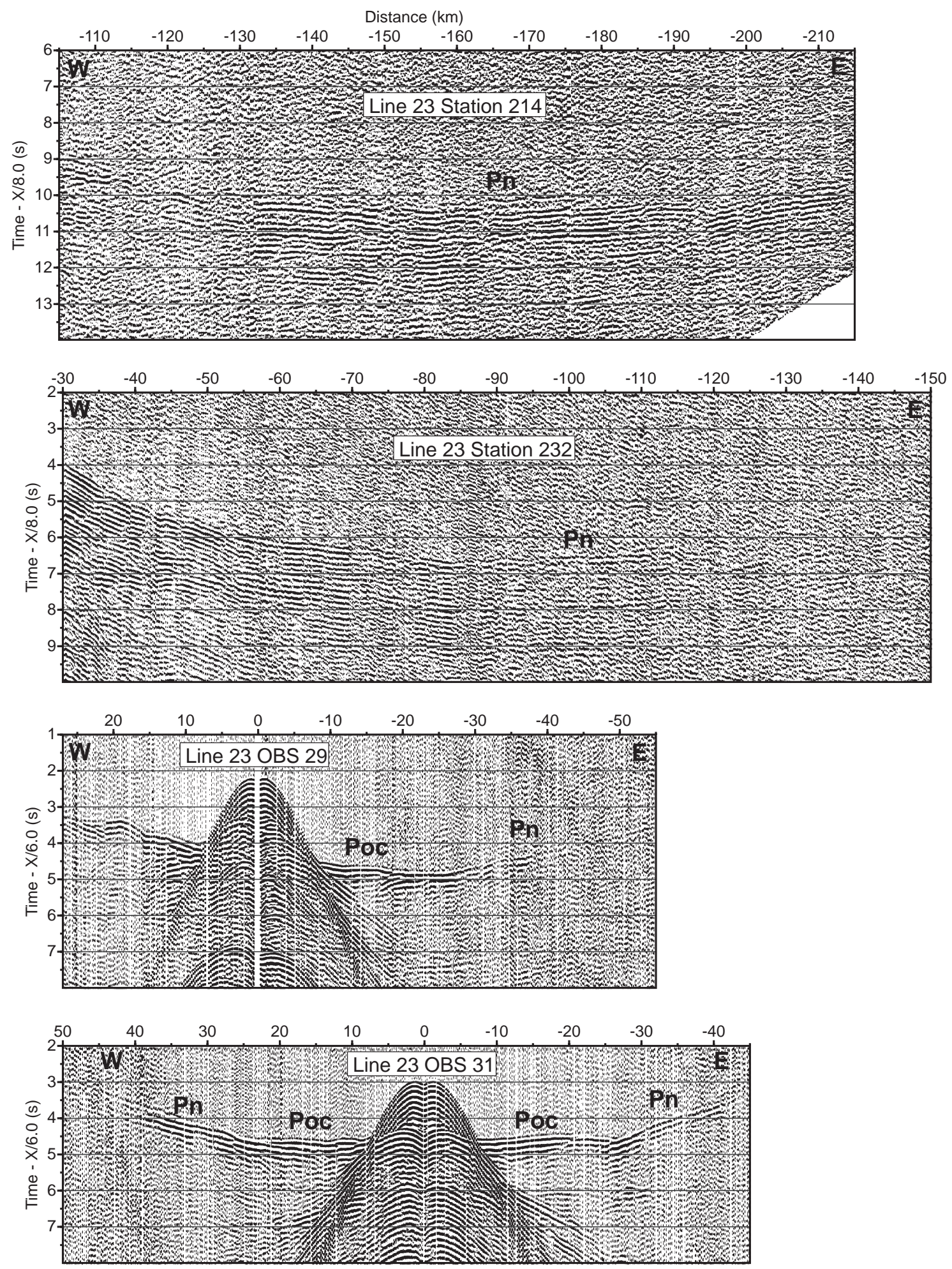
can be identified at all. Here the arc terrane extends westward to at least the coast as suggested by the velocity model (the $7 \mathrm{~km} / \mathrm{s}$ contour is probably limited to the arc or PSP crust) and likely is part of the Coastal Range based on surface geology. However, across the Longitudinal Valley from the Coastal Range continental basement material of the Central Range outcrops leaving little or no room for the forearc block. We suggest that the forearc block is beneath the inferred crustal-scale thrust fault and has probably been overthrust by the arc and coherent PSP lithosphere. However the fate of the forearc block remains uncertain due to insufficient ray coverage in deeper portions of the model, as discussed below.

The portion of the model that is well resolved (above the yellow dashed line in Fig. 8) reaches a maximum depth of $25 \mathrm{~km}$ beneath the remnant arc and is elsewhere limited to the upper 10-15 km. This is due to the oceanic crust offshore, which causes most rays to turn in the uppermost mantle, and it is also a result of the velocity inversion, noted above, which is present in the western half of the model. Because of the velocity inversion most of the recorded energy follows raypaths in the higher velocity overriding blocks. The deeper part of the model is based largely on arrivals to only a few land stations in the foothills, such as station 214 (Fig. 7), so it is not well resolved. In fact, we infer that the apparent velocity inversion beneath the Huatung basin at the eastern part of the line $(\sim 15 \mathrm{~km} ; x=150-200 \mathrm{~km})$ is an artifact due to this lack of deep ray coverage and expect that mantle velocities extend to the base of the model or to a possible tectonic boundary as shown in the interpretation. Finally, even though details of the deep structure are not resolved, the observed travel-times to large-offset stations absolutely require a thick crustal section beneath Taiwan.

\subsection{Northeast Taiwan/Ryukyu arc transect}

Northern and Northeastern Taiwan experienced arc-continent collision earlier and for a longer period than areas to the south and now experience interaction with the Ryukyu arc and a changing role for the PSP. The Line 16 transect shows the late stage structure of the collision and gives key information about the PSP's transition from collision to subduction, which completes the subduction polarity reversal.

\subsubsection{MCS data}

The northern transect extends from the coast seaward across the Ryukyu forearc basin. The primary onshore/offshore data set was acquired along Line 16 at the northern edge of the basin, and an additional MCS/OBS line, Line 14, was acquired subparallel to this about 15-20 km south (Fig. 1). Plots of both MCS profiles are shown in Fig. 9. Line 16 shows relatively rough seafloor morphology and few coherent reflections due to active deformation and its position near the sediment/basement contact at the north side of the Nanao forearc basin. Line 14 crosses the middle of the Nanao basin displaying a well-developed sedimentary section but a complicated underlying basement structure. The complicated structure on both of these lines results from deformation of the Ryukyu arc basement, which has been segmented by NW-oriented strike slip faults related to extension in the Okinawa trough (Hsu et al., 1996), and the basement beneath trace \#5000 (Line 14) and at the end of Line 16 is uplifted by the subducting Gagua ridge (Fig. 9) (Schnürle et al., 1998; McIntosh and Nakamura, 1998a). Lallemand et al. (1999) and Font et al. (2001) documented strike slip faults within the Ryukyu accretionary prism trending parallel to the trench and then curving northward at the western end of the trench. These faults are crossed by Lines 14 and 16 and account for some of the deformation at their western ends as shown in Fig. 9.

\subsubsection{Line $16 O B S$ and land data examples}

The record sections along this transect display a complicated configuration indicative of the complex subsurface structure these data sample. Land station 114 was located in the Huehshan Range and station 122 was located near the Lishan fault in the Central Range (Figs. 1 and 2). The western $35 \mathrm{~km}$ of both of

Fig. 7. Land and OBS record sections from Line 23. The land stations are displayed with an $8 \mathrm{~km} / \mathrm{s}$ reduction velocity, with station 214 showing Pn arrivals to $215 \mathrm{~km}$ offset. The OBS sections are displayed at a reduction velocity of $6 \mathrm{~km} / \mathrm{s}$ to help mark the crossover from rays turning in the oceanic crust (Poc) to rays turning in the upper mantle (Pn). The crossover occurs at offsets of about $25 \mathrm{~km}$ indicating normal oceanic crustal thicknesses. 
these sections shows a dramatic increase in firstarrival travel-time from west to east (Fig. 10). Part of this is due to the eastward sloping seafloor, but it also reflects a transition from high-velocity Tananao
Schist, exposed at the coast, to a thick offshore sedimentary wedge. The shadow zone, especially apparent in the station 122 record, suggests the boundary for this transition is steep or possibly places

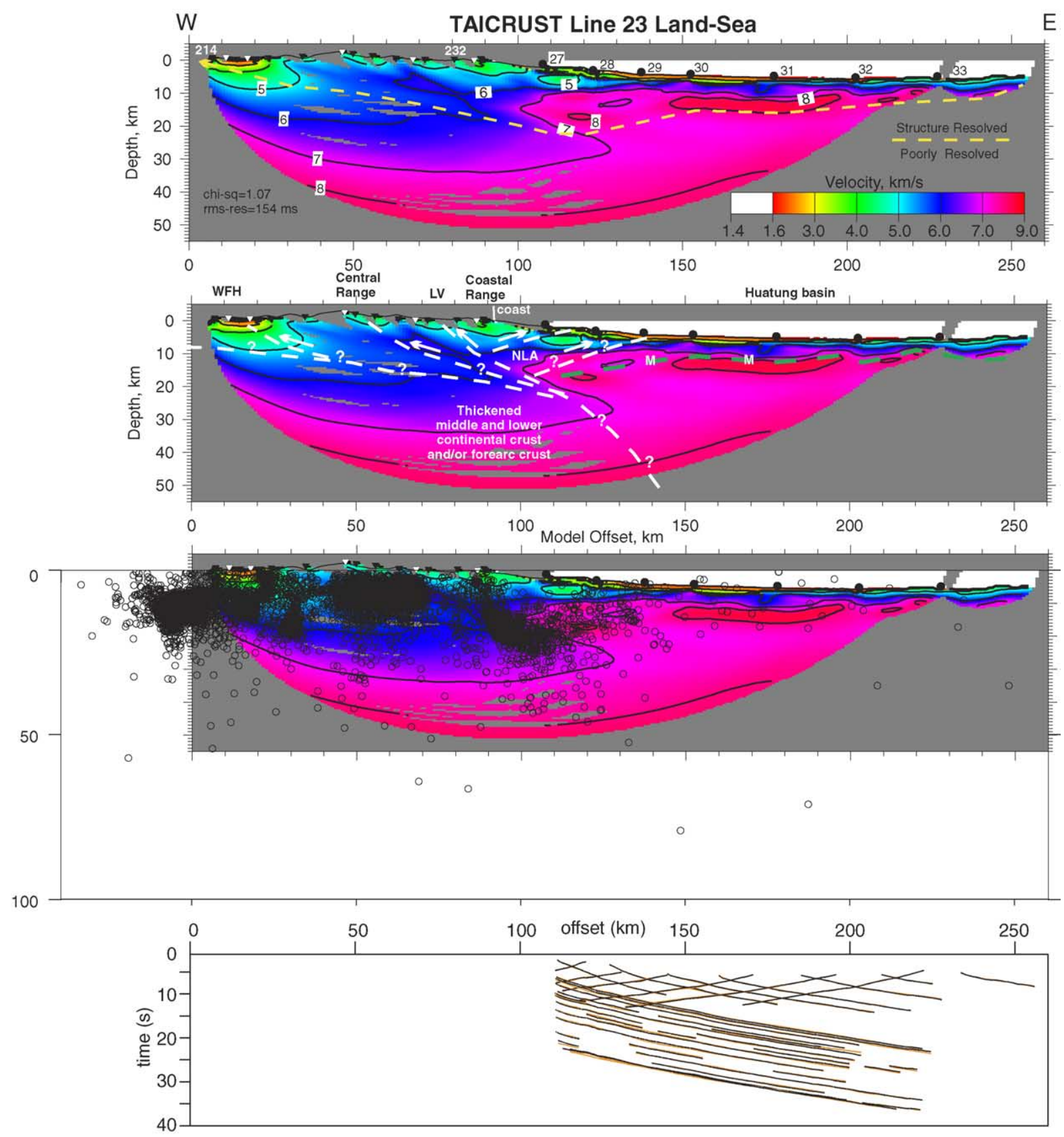

Fig. 8. Tomographic model along Line 23 onshore/offshore transect. This figure is organized in panels identical to Fig. 5. Green dashed line labeled $\mathrm{M}$ is Moho; $\mathrm{WFH}=$ Western foothills; $\mathrm{LV}=$ Longitudinal valley; NLA=North Luzon arc. 


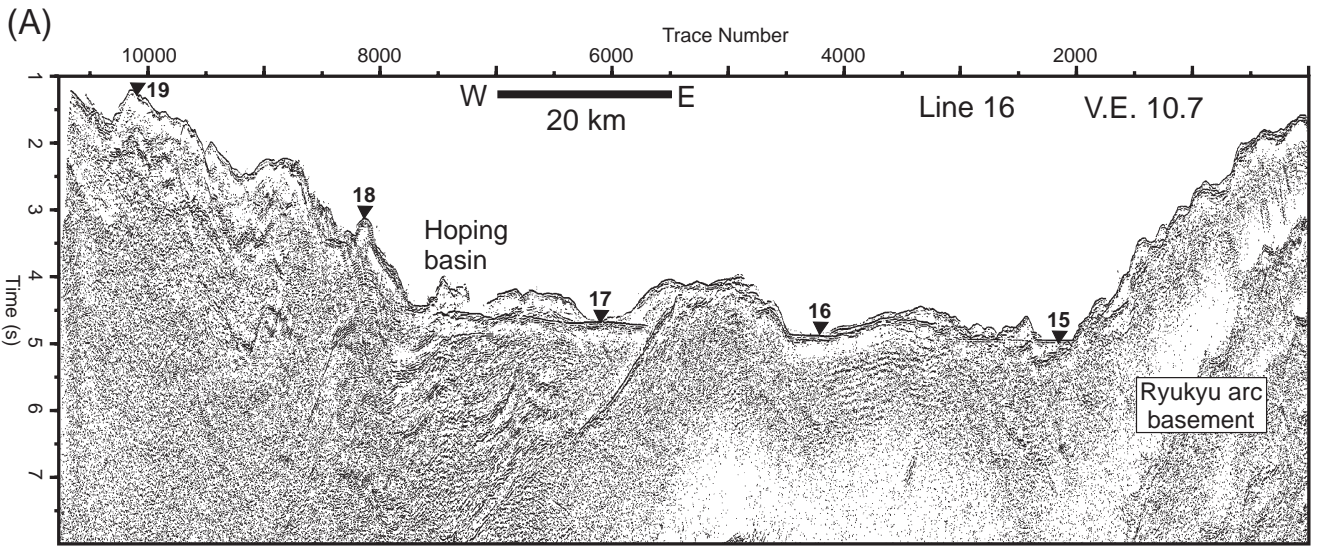

(B)

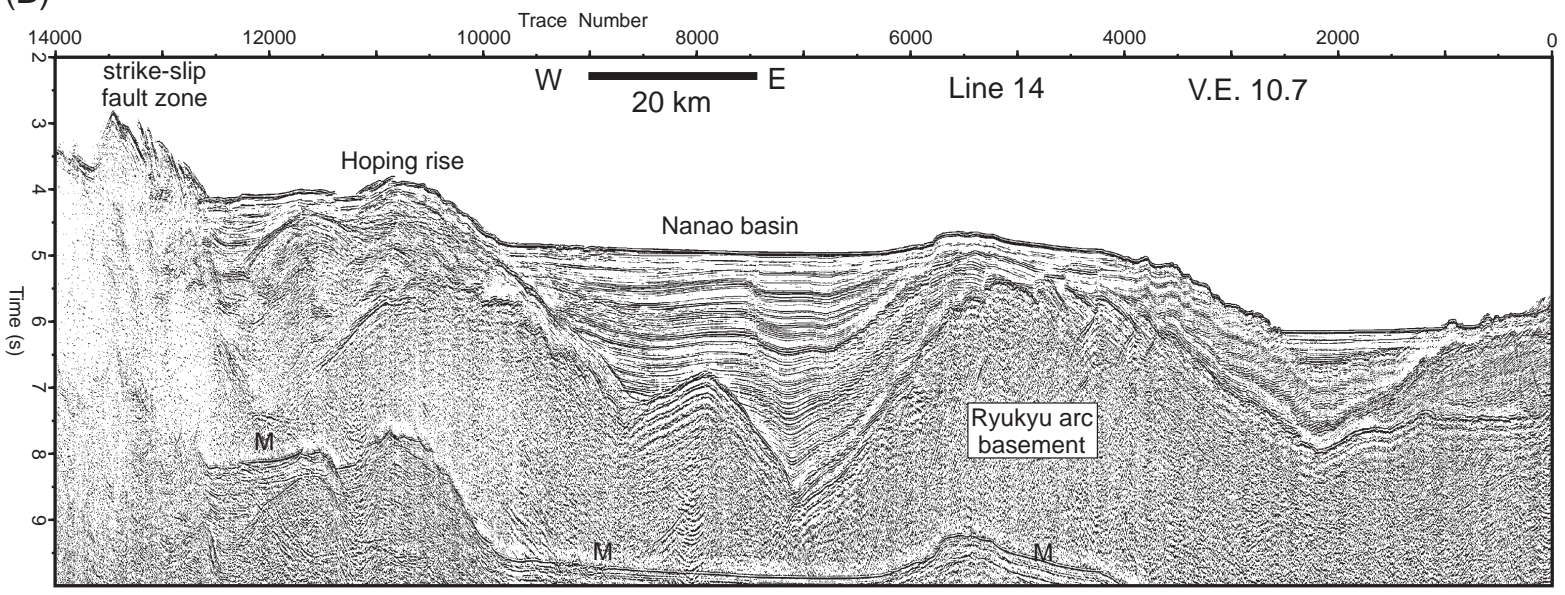

Fig. 9. MCS data from onshore/offshore Line 16 and nearby Line 14. Line 16 traversed the heavily deformed slope and Hoping basin and in its eastern half crossed the Ryukyu arc basement. Just to the south, Line 14 illustrates the highly faulted western limit of the Ryukyu accretionary wedge, the Nanao forearc basin, and the uplifted Ryukyu arc basement block, beneath which the Gagua ridge subducts. Multiple reflections marked with $\mathrm{M}$ and OBS positions marked with triangles. Note also that these sections are vertically exaggerated (10.7:1) to reveal structure and stratigraphy.

schist over the lower velocity sedimentary material. Beyond offsets of $85 \mathrm{~km}$ on the station 122 section the apparent velocities become large, suggesting a dip reversal in the basement surface and/or raypaths through higher velocity rocks. OBS 18 documents the presence of a thick sedimentary section with low apparent velocities to offsets of at least $25 \mathrm{~km}$ to the west and $15 \mathrm{~km}$ to the east. In contrast, OBS 15 was positioned very close to the contact between sediment and the Ryukyu arc basement. Its relatively high apparent velocities indicate raypaths through the arc terrane and also reflect the rapidly shallowing seafloor east of the instrument location (Fig. 9).

\subsubsection{Line 16 model description, observations, and interpretation}

The tomographic model, presented in the same manner as the previous transects, shows a remarkable correspondence to primary features known from geologic mapping along the transect (Fig. 11). At the western end the shallow structure indicates material with velocities $4-5 \mathrm{~km} / \mathrm{s}$ across the Huehshan Range and Lishan fault. East of the Lishan fault the velocity contours steepen and higher velocity material of the Central Range approaches the surface. A data gap prevents the model from extending all the way to the surface near the east coast, but the model shows 

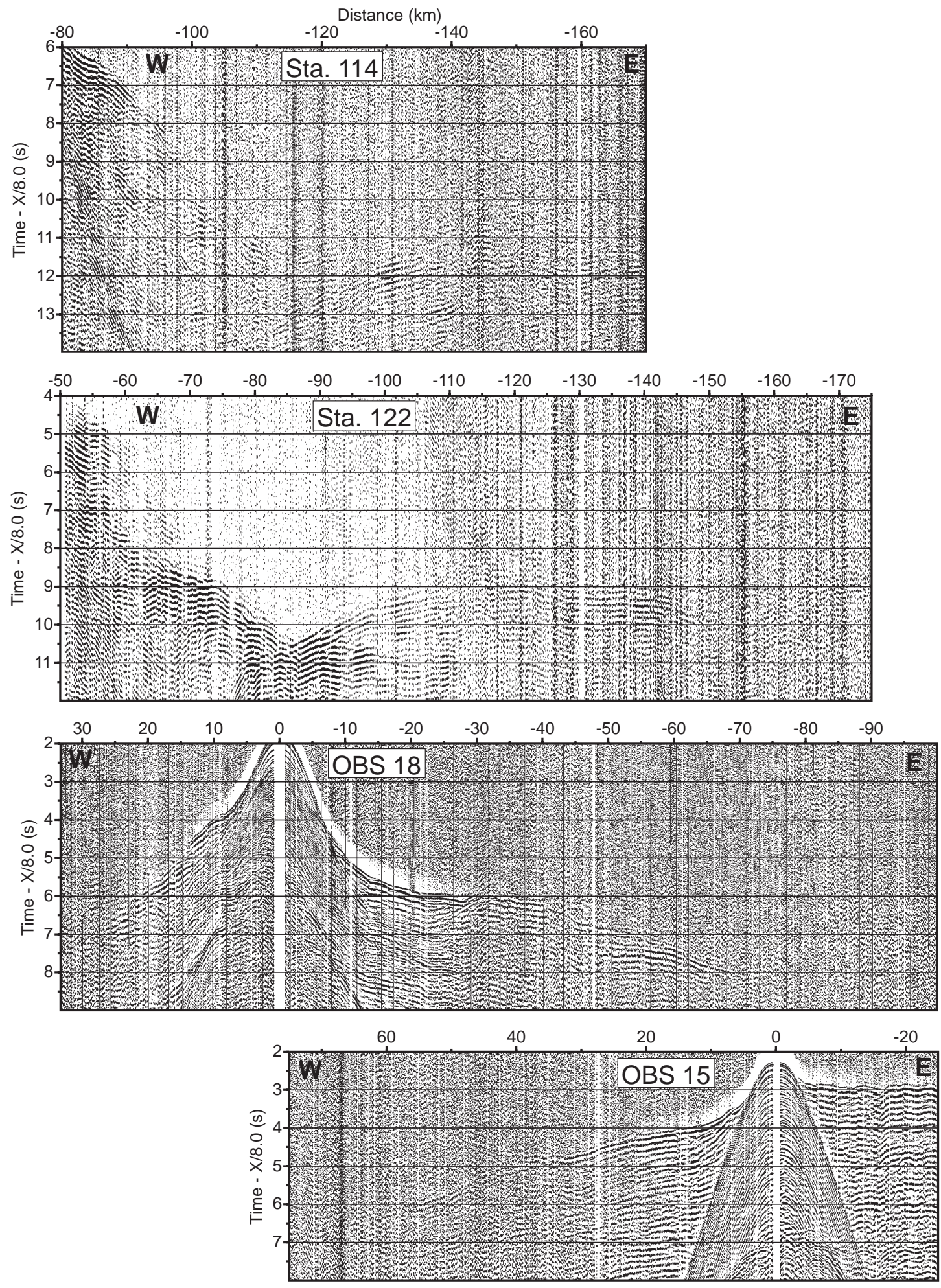
material with velocities of 6-7 km/s, implying a midcrustal source, at shallow levels in the vicinity of the coast. At deeper levels below the coastal and near shore area the velocity contours indicate an inversion with depth suggesting that tectonic blocks to the east, such as the PSP or Ryukyu arc, are being thrust under this northeast end of the Central Range. About $10 \mathrm{~km}$ east of the coast there is an extreme change in velocity structure with velocities $<4 \mathrm{~km} / \mathrm{s}$ extending to $10 \mathrm{~km}$ depth and velocities $<5 \mathrm{~km} / \mathrm{s}$ extending to $17 \mathrm{~km}$ depth. At $x=130 \mathrm{~km}$ the $5 \mathrm{~km} / \mathrm{s}$ contour shallows abruptly to the east delineating the basement complex of the Ryukyu arc. The low velocity zone apparently represents sedimentary material between the uplifted Mesozoic continental margin basement to the west and the Ryukyu arc.

Our first-order interpretation, based on the velocity structure, surface geology, and seismicity, shows a possible thrust detachment extending from beneath the Huehshan range (although expected to go farther west), getting progressively deeper beneath the Central Range, and possibly connected to a steep fault segment below the coast. Above the detachment we show a major west-vergent thrust fault, which is indicated by the velocity contours and could be responsible for uplift of the Central Range core. The velocity inversion beneath the coastal area noted above suggests a possible thrust boundary between the Central Range and terranes to the east. The sub-horizontal dashed boundary at 20 $30 \mathrm{~km}$ depth in the eastern two-thirds of the model marks the approximate top of the PSP. At this latitude the PSP is known to be subducting beneath the Ryukyu arc at a depth of $\sim 20-25 \mathrm{~km}$ from analysis of north-south refraction profile EW9505-1 $(x=175 \mathrm{~km}$ Fig. 11) (McIntosh and Nakamura, 1998b; Wang et al., 2002, 2004) and the composite velocity model developed by Font et al. (2003) also places the PSP in this position. Furthermore, the thick zone of relatively low velocity material between OBSs 18 and 19 restricts the position of the PSP, as velocities appropriate for oceanic crust occur below $\sim 20-25 \mathrm{~km}$ depth. Above the subduction plate boundary (or top PSP) we interpret a steep fault at $x=140 \mathrm{~km}$ representing a primarily strike slip fault, which offsets the Ryukyu arc terrane. This fault is somewhat speculative but it is suggested by increased seismicity $(x=140-150)$, delineated by the NNW bathymetric contours north of Line $16\left(\sim 122.2^{\circ} \mathrm{E}\right)$, and it is likely related to opening of the Okinawa trough to the north (Fig. 1). This and other faults have been previously interpreted by Hsu et al. (1996) and Lallemand et al. (1999) on the basis of bathymetric, magnetic, and gravity interpretation. An additional zone of enhanced seismicity is visible at $x=200 \mathrm{~km}$ (Fig. 11) and is due to the Gagua ridge (on the PSP), which subducts beneath this part of the RAB. The queried fault at the extreme western end of the model is based only on the seismicity, as shown in the bottom panel, but it is included to indicate probable deep crustal deformation below the inferred detachment.

Although our interpretation in Fig. 11 is clearly non-unique, given the lack of model resolution at depth, we believe that it is consistent with the available data. The inferred detachment is apparently required in some form, due to large-scale shortening documented in the Western Foothills fold and thrust belt (Suppe, 1980, 1981), and it is consistent with current deformation patterns according to geodetic modeling (e.g., Hsu et al., 2003). It is likely that this fault system deepens to the east, as indicated by seismicity, and, as a crustal-scale ramp, it is a mechanism to emplace upper- to mid-crustal material of the continental margin into the Central Range. However, the geometry of this fault system is not well determined from the velocity model except that the velocity inversions noted above, on both sides of the Central Range, should be above a regional detachment. The steeply dipping fault segment at $x=90 \mathrm{~km}$ is based solely on the trend of seismicity, which suggests a seismogenic boundary extending from about 20 to $60 \mathrm{~km}$ depth

Fig. 10. Line 16 land and OBS record sections. The land stations (114 and 122) both show a spectacular delay in the first arrival times from the near shore shots to those $\sim 35 \mathrm{~km}$ east. This spans transition from schists and gneiss, which out crop at the coast, to deformed sedimentary rocks with a deep basement. The sudden increase in apparent velocity corresponds to where the Ryukyu arc basement block slopes up to the east, emerging at the seafloor between OBSs 16 and 17. The OBS sections confirm the thick low-velocity sedimentary section in the western part of the offshore line and show the effects of the emergent Ryukyu arc basement in the eastern half of the section. 

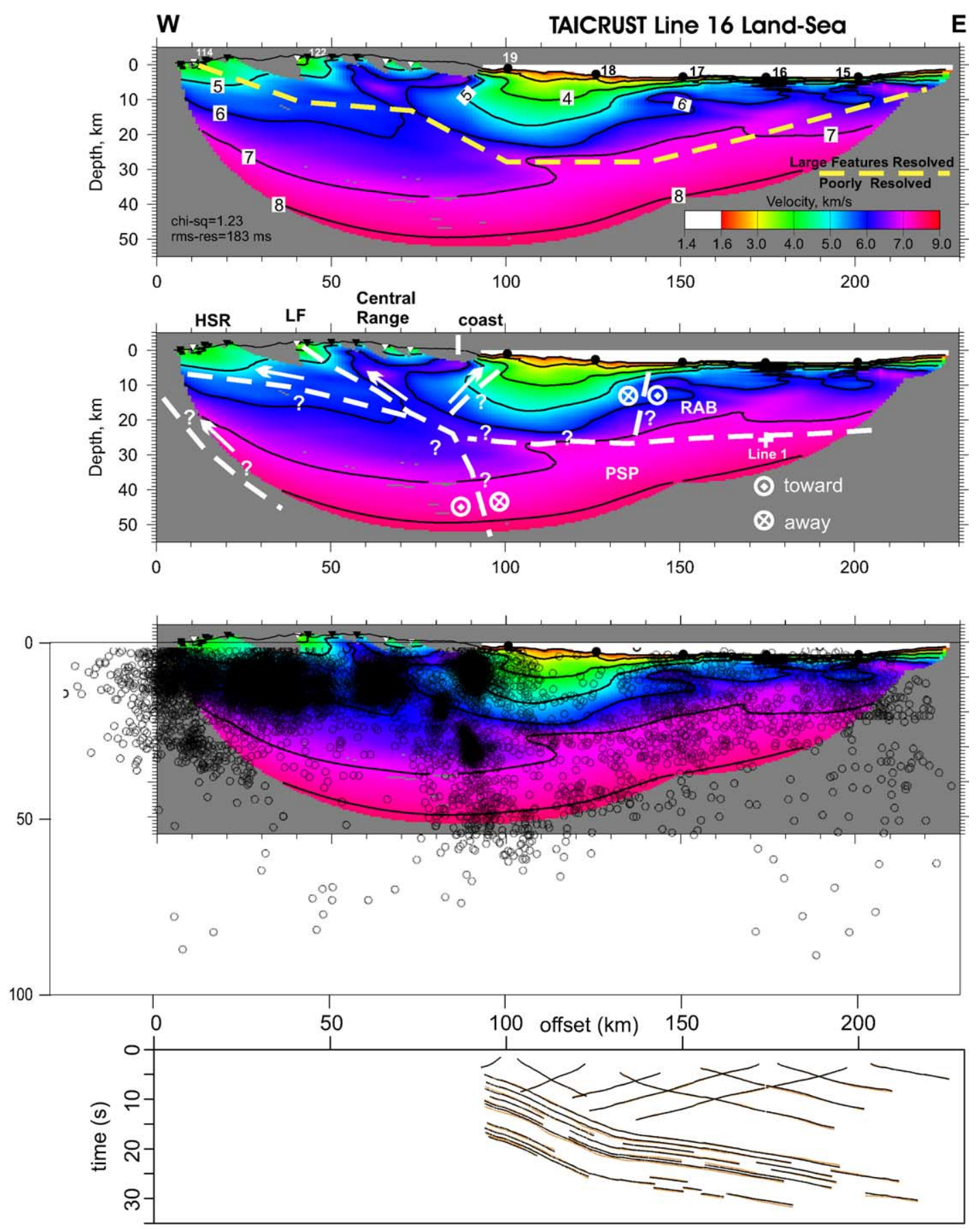

Fig. 11. Tomographic model along Line 16 onshore/offshore transect. This figure is organized in panels identical to Fig. 5. The circular symbols mark faults with probable strike slip components. HSR =Huehshan Range; LF=Lishan fault; RAB = Ryukyu arc basement; PSP=Philippine Sea plate. Line 1 label marks intersection of N-S seismic line EW9509-01. 
dipping $70-80^{\circ}$ to the east. Using a relocated subset of the CWB catalog to interpret prominent fault boundaries in this vicinity, Carena et al. (2002) also noted this steep zone of seismicity, interpreting that it is the downdip extension of the regional detachment. We interpret that this zone currently represents a transpressional plate boundary between the EUP and the PSP. With several lines of evidence noted above, which place the PSP at 20-25 km depth, we infer that the intense zone of relatively deep seismicity marks the plate's westward limit. Thus we expect this to be a zone of transpression with the PSP moving both toward the boundary and along it to the northwest. If correct, this means that the PSP is still colliding with the Eurasia continental margin at this latitude, but the point of contact is at depth and possibly in the middle and lower continental crust.

\section{Discussion}

\subsection{Comparison to other velocity models}

Numerous researchers have investigated the velocity structure of Taiwan using both active-source and earthquake seismology. The TAICRUST project is the most comprehensive active-source project to investigate the deep crustal structure of Taiwan and its surrounding area, but, as noted above, the initial analysis of the data sets did not include the combined onshore/offshore analysis. The original travel-time modeling for Lines 29 and 33 was performed using RAYINVR and a layered parameterization. These models (Nakamura et al., 1998; Chen and Nakamura, 1998) used reflected arrivals in addition to turning rays to locate the position of the subducting EUP, defined its crustal thickness to be $\sim 11 \mathrm{~km}$, and determined an initial velocity structure of the N. Luzon arc. Yeh et al. (1998) and Hetland and $\mathrm{Wu}$ (1998) modeled the Line 23 transect using only data recorded by the land instruments. Both groups interpreted thick crust, $35-50 \mathrm{~km}$, beneath the east coast of Taiwan. Shih et al. (1998) modeled land data along the Line 16 transect and also derived a very simple model showing continental crust to $\sim 47 \mathrm{~km}$ depth beneath the east coast with rapidly thinning crust offshore to the east. Hetland and $\mathrm{Wu}$ (2001) also modeled the land data along Line 16, finding evidence for thick continental crust beneath the Central Range and, consistent with our results, a thick zone of lowervelocity material just offshore and indications for a relatively deep position of the PSP (base PSP at $\sim 30$ $\mathrm{km}$ near the coast). The lack of offshore constraints forced these models to be quite simple, so they agree in general with the velocity structure presented here but do not convey many of the critical features apparent in our joint onshore/offshore tomographic models. A previous OBS-only model for offshore Line 16 presented by Wang and Chiang (1998) shows the shallow basement surface of the Ryukyu arc block and rapid westward deepening of the velocity contours between OBSs 18 and 19 similar to that shown in our model (Fig. 11). The OBS-only model for offshore Line 23 developed by Yang and Wang (1998), using a layer-based approach, differs from the offshore portion of our model primarily by its westward thickening lower crust. In contrast, with the addition of land stations and the unbiased tomographic approach, we found essentially normal oceanic crustal thickness across the Huatung basin to the base of the slope between OBSs 29 and 30 (Fig. 8). Crustal thickness is poorly determined west of this point but thickening to $18-20 \mathrm{~km}$ due to the $\mathrm{N}$. Luzon arc below OBS 27 is likely. This point is important because it suggests that deformation of the PSP has not thickened the crust east of the remnant N. Luzon arc and seismicity (Fig. 8) suggests deformation is focused in this zone of thicker, arcmodified crust.

The well-developed seismic network in Taiwan and frequent local and regional earthquakes have allowed numerous researchers to develop crustal-scale velocity models here. The early model by Roecker et al. (1987) showed a crustal and upper mantle low velocity anomaly beneath nearly all of Taiwan, which in the south is clearly associated with EUP subduction beneath the PSP and in the north is inferred to represent the remnant EUP continental margin. Interestingly, their velocity model for northern Taiwan has a steep boundary between low-velocity material to the west and higher velocity rocks to the east at a similar location where we interpret the western limit of the PSP contacting the lower continental crust (Fig. 11). Using a much improved and expanded data set, 
Rau and Wu (1995) developed a tomographic model, which shows generally thick crust $(>40 \mathrm{~km})$ beneath the Central Range and, in northern Taiwan, an eastward thickening crustal section bounded on the east by steep velocity contours and an apparently vertical seismic zone similar to the Roecker et al. (1987) model and consistent with our Line 16 transect (Fig. 11). Farther to the south the Rau and Wu (1995) model shows an eastward thickening crustal section and velocity contours shallow rapidly at the east edge of the model. Unfortunately our Line 23 model (Fig. 8 ) is poorly resolved deep below the Central Range, so comparisons there are not useful. However, the suggestion of a shallow high velocity zone in the Rau and Wu (1995) model may be related to the N. Luzon arc and PSP present just east of their model and shown by our model to produce a probable velocity inversion beneath the coast and near shore areas at about $23^{\circ} \mathrm{N}$. Cheng et al. (1998) produced a 3-D tomographic velocity model for southeastern Taiwan using earthquake travel-times supplemented with arrivals from the TAICRUST airgun shots. The section through their model nearest Line 29/33 has very similar velocities and shape to that shown in the upper $20 \mathrm{~km}$ of Fig. 5 except that high velocity zones associated with Hengchun Peninsula and the N. Luzon arc seem to be shifted $\sim 20 \mathrm{~km}$ eastward. Cheng et al. (1998) used seismicity patterns to help interpret their velocity model, similar to our approach, and they also concluded that the Luzon arc is apparently detaching from the forearc block to the west. In summary, the earthquake-based tomographic models generally show features similar to our models, and they typically provide information on deeper structures, but due to closer receiver spacing, receiver coverage into the offshore areas, and a large number of airgun shots, our models provide structural details of eastern Taiwan that were previously unclear.

\subsection{Transition from subduction to collision}

Perhaps the earliest hint of collision is deformation of strata in the Luzon trough forearc basin. Numerous workers have documented this process, which begins at the arcward part of the accretionary prism and gradually encroaches on the arc at higher latitudes (Reed et al., 1992; Lundberg et al., 1997; Malavieille et al., 2002) and is readily visible in the bathymetry between $21^{\circ}$ and $22^{\circ} \mathrm{N}$ (Fig. 1). Although this essentially reflects rapid growth of a doubly vergent accretionary prism, the fact that a huge mass of material has been emplaced on the PSP forearc may have a profound effect on the style of collision. Specifically, instead of allowing the PSP forearc to override the continental margin as the "upper plate", the massive accretionary pile sitting above both the forearc block and the subducting plate probably helps force arcforearc detachment. Evidence for detachment was discussed above and is shown in Fig. 5 at latitude $22.2^{\circ} \mathrm{N}$ where the forearc basement block is depressed to a depth of at least $10 \mathrm{~km}$, it is offset from the $\mathrm{N}$. Luzon arc, and there is a very active zone of seismicity between these two blocks marking the detachment. If this is the case, what becomes of the forearc block? If we measure the distance between the arc and the westward edge of the forearc block along this transect it is $\sim 80 \mathrm{~km}$ (Fig. 8). To the south at $21^{\circ}$ this distance is $\sim 100 \mathrm{~km}$ as measured from the Hengchun ridge (extension south of the Hengchun Peninsula; Fig. 1) to the arc. Farther to the north, along Line 23 (Figs. 1 and 8), we are unable to locate the forearc block with any certainty either in surface geology or in our model of the subsurface. However, if we simply measure the distance between the eastern margin of the Central Range, composed of uplifted continental margin rocks, and the remnant arc, then the available space is a maximum of about $40 \mathrm{~km}$. We infer that the forearc block has been at least partially thrust beneath the northwestward advancing PSP, whose leading edge is now the remnant N. Luzon arc. Fig. 12, based on the three velocity models but showing more speculative interpretation below the resolved model depth, shows that the forearc block may have been thrust beneath the remnant arc. Fig. 8 has two key pieces of evidence to support this interpretation: (1) The velocity inversion at $x=100-120 \mathrm{~km}$ shows oceanic crust and mantle above material with crustal velocities $<7 \mathrm{~km} / \mathrm{s}$, i.e., the forearc block; (2) A zone of very high seismicity coincides with this velocity inversion and confirms it as an active tectonic boundary. A further result of forearc detachment is accelerated deformation of the remnant arc. This is indicated diagrammatically by westward-dipping thrust faults in our interpretation (Fig. 8), by the enhanced seismicity beneath the eastward arc slope $(x=100-140 \mathrm{~km})$, and by deformation apparent in the MCS data (Fig. 6). 

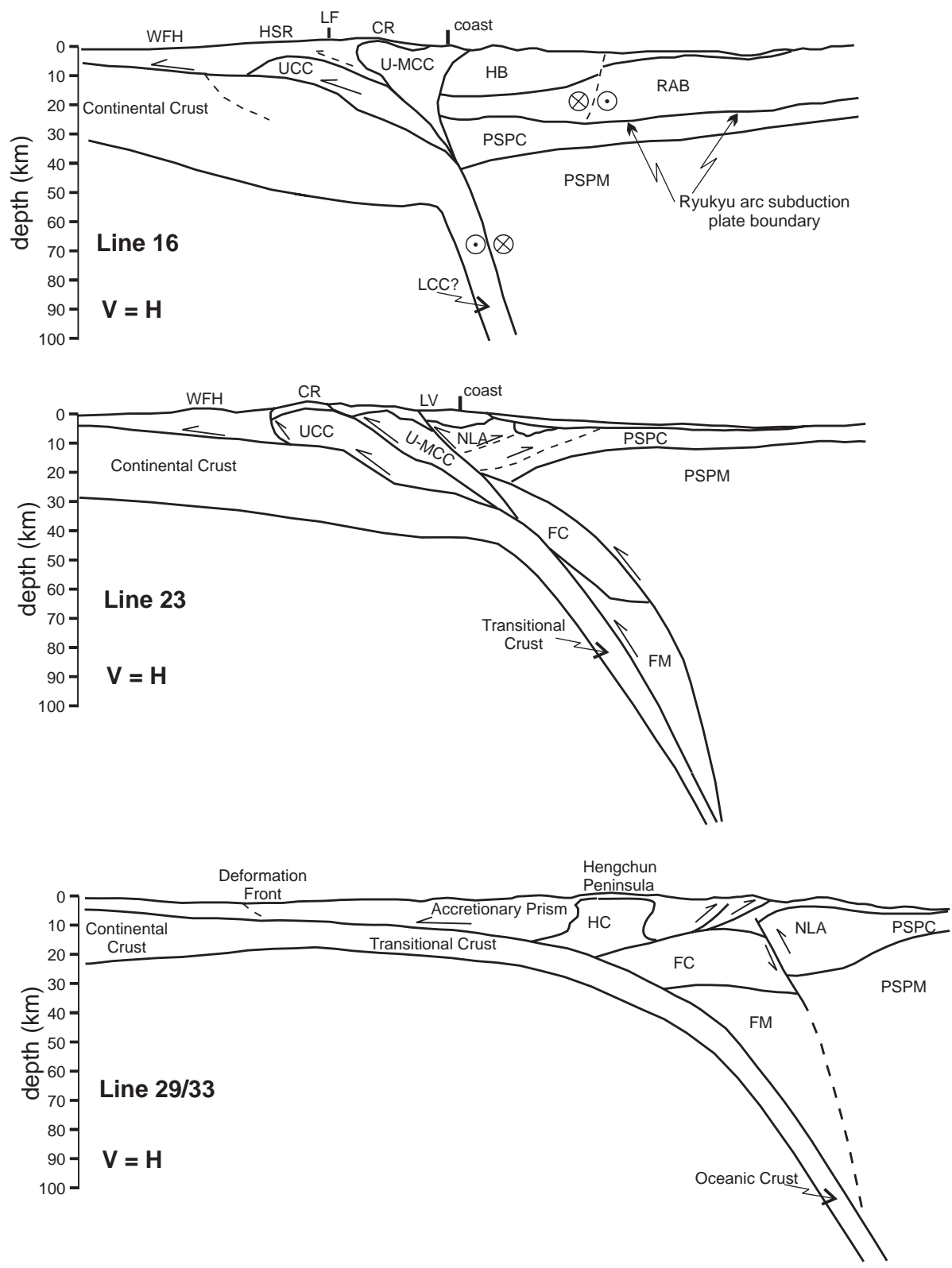

Fig. 12. Schematic summary figure showing crustal-scale cross sections along the geophysical transects. The upper portions of the sections are based directly on the velocity models, while the deeper portions have limited constraints from seismicity (Figs. 5, 8 and 11) and should be considered speculative. These sections assume a structural style in which upper- to mid-crustal detachments develop in underthrust continental crust and lead to emplacement of the Paleozoic-Mesozoic metamorphic rocks in the Central Range. FC (FM)=forearc crust (mantle); UCC, MCC, LCC = upper, middle, lower continental crust; $\mathrm{HC}=$ Hengchun core; TC = transitional crust; WFH=Western foothills; $\mathrm{LV}=\mathrm{Longitudinal}$ valley; NLA=North Luzon arc; HSR=Huehshan Range; $\mathrm{CR}=$ Central Range; LF=Lishan fault; HB=Hoping basin; RAB=Ryukyu arc basement; PSPC (PSPM) $=$ Philippine Sea plate crust (mantle). 
With arc-forearc detachment and subsequent forearc underthrusting, our interpretation of the transition from subduction to collision is similar to models proposed by Chemenda et al. (1997) and Malavieille et al. (2002). These models were developed on the basis of surface geology, analog and numerical modeling, and supported with the addition of multibeam bathymetry and shallow-penetration seismic reflection data. Thus, while consistent with surface features, the deeper structure predicted by these models has been unproven. Our models for Lines $29 / 33$ and 23 now provide detailed geophysical constraints to depths of up to $25 \mathrm{~km}$ and span the zone from incipient collision to full collision. While our models appear to support the process of forearc detachment and underthrusting it is less clear that igneous crustal material from the subducting plate contributes significantly to the core of the southern Hengchun Peninsula as suggested by Malavieille et al. (2002). Chang et al. (2001) also presented a section (Profile a) showing continental basement accretion at this latitude along with the required continental crust subduction. As shown in Fig. 5, the core of this zone has a velocity between 5 and $6 \mathrm{~km} / \mathrm{s}$. This velocity range could include igneous continental crust or the relatively thin uppermost part of the transitional crust (Nakamura et al., 1998; Nissen et al., 1995), but it also includes unmetamorphosed to moderately metamorphosed accreted sandstones and greywackes, which fall in a velocity range of $\sim 5-6.4 \mathrm{~km} / \mathrm{s}$, as demonstrated by the work on Franciscan (California) samples by Stewart and Peselnick (1978). We suggest that with only slightly thickened transitional crust subducting here, this body is more likely to be accreted sedimentary material, some of which has been uplifted as a result of mass flow in this doubly vergent accretionary system.

\subsection{Lishan fault}

The Lishan Fault is one of the more remarkable features of the Taiwan orogen due to its dramatic morphologic character and continuity, which are matched by its enigmatic tectonic role. It is now widely accepted that the Lishan fault is a west-dipping reverse fault forming the boundary between the Hsuehshan range, to the west, and the Backbone range (Clark et al., 1993; Tillman and Byrne, 1995;
Lee et al., 1997). The stratigraphic relations across the fault suggest that it may have bounded an early Tertiary sedimentary basin on the Chinese continental margin, with thick accumulations of Eocene to Oligocene sediments in the "Hsuehshan" basin to the west and a probable basement high toward the outer continental margin (Teng et al., 1991). The more recent tectonic history of the fault and adjacent rocks is characterized primarily by NW-SE compression associated with the ongoing arc-continent collision (Lee et al., 1997), and Tillman and Byrne (1995) for example, suggest that the original sedimentary basin and basement block to the east, may have been deformed and transported west as part of the Taiwan thrust belt. In this case the Hsuehshan basin has been inverted to create the Hsuehshan range, with slip on the Lishan fault reversed to form a backthrust in the westward growing thrust belt. Our velocity model (Fig. 11) suggests that the major structures in the vicinity of the Lishan fault are west-vergent, crustalscale thrust faults involving the continental margin basement. Although we do not image the fault zone itself, we favor an interpretation similar to Huang et al. (1997) in which a subduction complex, represented by material of the current Backbone Range, was thrust westward over the continental margin until the deformation front encountered the Hsuehshan basin. At that point the Hsuehshan Range began to form in juxtaposition with the Backbone Range. During this time, we suggest that the underthrust metamorphic basement developed a midcrustal detachment resulting in thrust emplacement of what is now part of the eastern Central Range (block labeled U-MCC in Fig. 12). In addition to this block of mid-crustal rock emplaced at shallow levels, our velocity model (Fig. 11) suggests additional structure in the basement with westward deepening at $x=30 \mathrm{~km}$. If valid, this could reflect an Eocene basement structure, possibly part of the original Hsuehshan basin. Alternatively, this structure could indicate the presence of another crustal thrust slice. If the original detachment over the continental margin basement were subsequently abandoned, a deeper detachment could have developed in the underthrust continental margin basement resulting in a large basement duplex structure. Fig. 12 suggests this possibility, in which the Lishan fault may currently act as a component of the thick, but still deforming, hanging wall. The observed backthrust 
relationship of the Lishan fault may have developed during the earlier compressional deformation or during emplacement of our interpreted crustal duplex.

\subsection{Status of collision in Northeast Taiwan}

In the description of our Line 16 tomographic model we interpreted that the western edge of the PSP is at a depth of $>20 \mathrm{~km}$ and actively colliding with the middle-lower continental crust or the remnant slab of the EUP as it subducts. On the basis of seismicity patterns and waveform modeling, Kao and Jian (2001) proposed that in the transition from arc-continent collision in east-central Taiwan to PSP subduction beneath the Ryukyu arc the collision process continues along the western edge of the subducted PSP. They termed this slab-continent collision because collision continues even though the PSP is subducting. The fact that there is horizontal compression in the strike direction of the subducting PSP was noted previously in compilations of earthquake P-axes by Kao and Chen (1991) and Kao et al. (1998), and the distribution of these events is restricted to the upper $65 \mathrm{~km}$ of the PSP slab. Furthermore Bos et al. (2003) showed updated regional tomography results and interpreted that the EUP and PSP slabs are probably in contact at $\sim 24^{\circ} \mathrm{N}$. Our interpretation of Line 16 (Figs. 11 and 12) is in full agreement with the slabcontinent collision interpretation and it provides additional constraints on the position of the PSP in the shallow portion of the Ryukyu subduction zone. Previous interpretations suggested that the PSP was perhaps much shallower near the coast at $24^{\circ} \mathrm{N}$ (Kao et al., 1998); however, the low velocity sedimentary pile shown in our velocity model (Fig. 11; HB in Fig. 12) restricts the PSP to depths probably $>20 \mathrm{~km}$. Although this could appear to contradict the presence of N. Luzon arc material in the Coastal Range just south of Hualien, GPS results (Hu et al., 2001) show clearly that north of $\sim 23.6^{\circ} \mathrm{N}$ the surficial units are decoupled from the PSP and thus do not constrain its position.

\subsection{Structural style of the orogen}

Because our data set focuses on the east side of Taiwan, we have not been able to image detailed structural architecture of the orogen. However, we can get a sense of how the collision process probably evolves from a largely thin-skinned process, i.e., subduction, in the south to deformation processes that more likely involve the entire crust and upper mantle. Our southernmost model shows the thin-skinned process of subduction, with the modification of slightly thickened subducting crust and, possibly associated with this, crustal-scale deformation of the forearc. Along the Line 23 transect, the velocity model and seismicity still suggest a relatively lowangle boundary beneath the Coastal Range and offshore to the east. This boundary is not defined below $25 \mathrm{~km}$ except for a concentration of seismicity, which may indicate steepening with depth (Fig. 8). It is instructive to note that the projected position of the shelf edge, extrapolated from southwest of Taiwan, would be approximately under the remnant N. Luzon arc at $23^{\circ} \mathrm{N}$. From previous seismic work across the Chinese continental margin and into the South China Sea, the crust reaches a full thickness of $25-30 \mathrm{~km}$ near the shelf edge and the transition to oceanic crust happens gradually over a distance of $\sim 200 \mathrm{~km}$ (Nissen et al., 1995; Pin et al., 2001). Thus, at $23^{\circ} \mathrm{N}$, roughly $200 \mathrm{~km}$ of gradually thickening transitional EUP crust and some or the entire forearc block may have passed below the arc in a thin-skinned subduction environment. On the other hand, the presence of upper- to mid-crustal rocks exposed in the Central Range just to the west requires that much or all of the continental margin crust is involved in collisional deformation, i.e., it has not passively subducted, but it has in some way detached and been uplifted or the whole crust and lithosphere has been thickened to result in the Central Range. Below we discuss likely mechanisms that could result in the observed structure.

In the literature there are three general classes for interpretation of the Taiwan orogen: (1) Gradual evolution from subduction to orogenesis with a primary detachment that reaches deeper structural levels to the east and results in a crustal-scale accretionary prism (Suppe, 1987); (2) Continental subduction followed by buoyancy-driven exhumation (Malavieille et al., 2002); (3) Lithospheric collision, where the low-angle subduction plate boundary evolves to a high-angle collisional boundary involving the crust and mantle lithosphere of both the EUP and PSP. The crustal-scale accretionary prism model is attractive because it seems to most easily explain 
the observed large-scale shortening within the sedimentary sections of the Western Foothills and the Hsuehshan Range. Furthermore, geodetically constrained modeling by several workers tends to support a shallowly dipping detachment, at least beneath the Western Foothills and western Central Range (Hsu et al., 2003; Loevenbruck et al., 2001). However, the geometry of such a system has not been adequately defined, and we now know that published sections such as shown in Suppe (1987, Fig. 15-11) require at least some modification to be consistent with the westward extent of the PSP, the thickness of the accretionary mass, and deformation of the N. Luzon arc as determined from our models and MCS data.

The model of continental subduction followed by exhumation is attractive because subduction is observed to at least as far north as $22.8^{\circ} \mathrm{N}$ (Wu et al., 1997) and tomographic models (Roecker et al., 1987; Rau and $\mathrm{Wu}, 1995)$ indicate the presence of crustal material at depths $>45 \mathrm{~km}$. If this represents the subducted transitional and continental crust, then according to the calculations of Van den Beukel (1992), it is well within the depth range where upper-crustal detachment would be expected due to buoyancy forces, thermal conditions, and friction along the existing lithospheric plate boundary. The result could then be emplacement of detached upper-middle crust in the Central Range with the remnant lower crust and mantle lithosphere continuing to subduct deep below the orogen and PSP (Fig. 12). This scenario could also potentially explain the lack of an identifiable Benioff zone north of $23^{\circ} \mathrm{N}$, by having the typically aseismic lower continental crust make up the EUP slab beneath Taiwan. Partial continental subduction may also be favored by the nature of the transitional crust. While crustal thickening is expected over a significant distance, as demonstrated southwest of Taiwan (Nissen et al., 1995), high seismic velocities of the lower crust $(>7 \mathrm{~km} / \mathrm{s})$ suggest that much of the thickening may be magmatically underplated mafic material associated with Eocene rifting (Pin et al., 2001). This type of thickened crust is less likely to retard subduction (e.g., Fig. 12, Line 23) due to its lower buoyancy and potential for further densification to eclogite after subduction. Another line of evidence supporting partial continental subduction and detachment is the remarkable con- tinuity of major exposed Paleozoic-Mesozoic units in the eastern Central Range. These units are continuous from north of Hualien to west of Taitung-a distance of nearly $200 \mathrm{~km}$ (Fig. 1). This continuity indicates a regional emplacement process, perhaps consistent with the $10+-\mathrm{km}$-thick crystalline thrust sheets predicted by the modeling of Van den Beukel (1992).

We also find the lithospheric collision model (Wu et al., 1997) attractive because deformation marked by active seismicity extends well below any proposed decollement in central and western Taiwan, thus suggesting deep, collision-related deformation. Furthermore, our models of Taiwan's eastern margin and seismicity patterns (Fig. 11) seem to document a steepening of the EUP-PSP plate boundary to near vertical off northeast Taiwan. Unfortunately, the crustal structure and location of the major fault boundaries are not sufficiently well known at this time to eliminate any of the three model classes, and, in fact, facets of each of these models in combination may be closest to reality. For example, the crustalscale accretionary prism model could incorporate thermal/buoyancy-driven crustal detachment as a large-scale thrusting and underplating process, and, as the orogen and plate boundary geometries evolve, deformation throughout the lithosphere may be more likely. In Fig. 12 the series of models essentially show this sort of evolution from south to north. We acknowledge a bias toward crustal detachment and large-scale thrusting in our proposed model as these processes seem more likely to be consistent with the observed shallow level shortening in the Western Foothills and Hsuehshan Range. However, our data do not rule out more of a bias toward lithospheric deformation, which could also produce significant shallow shortening as observed. To better differentiate among the models and the evolutionary development of the collision we must collect additional crustal and lithospheric-scale seismic data to illuminate the full structure of the orogen, better identify the active fault boundaries, and also determine if there is a slab beneath Taiwan, possibly with the upper crust removed. This work, combined with more horizontal and vertical deformation rates, more geodetic modeling, and geodynamic modeling should lead to a much better understanding of the Taiwan orogen and arccontinent collision in general. 


\section{Conclusions}

1. Our model across the Hengchun Peninsula, along with seismicity data, indicates that the forearc basement probably detaches from the N. Luzon arc somewhere in the vicinity of $22^{\circ} \mathrm{N}$. The detachment triggering mechanism is not known, but somewhat thicker $(11 \mathrm{~km})$ transitional crust is subducted here and rapid growth of the doubly vergent accretionary prism are likely factors.

2. With detachment of the forearc block, the remnant N. Luzon arc becomes the leading edge of the PSP. Our model at $23^{\circ} \mathrm{N}$ indicates that most of the collision-related PSP deformation occurs in the remnant arc and no crustal thickening of the PSP is present east of the arc slope $\sim 45 \mathrm{~km}$ from the coast.

3. Crustal material of the forearc block and/or continental margin rocks are present beneath oceanic crust and mantle just offshore of Taiwan at $23^{\circ} \mathrm{N}$. This velocity inversion probably marks part of the active plate boundary, as it is also a zone of intense seismicity.

4. North of Hualien $\left(24.1^{\circ} \mathrm{N}\right)$, our model suggests that slab-continent collision is an active process and that the position of the PSP is at $\sim 20 \mathrm{~km}$ depth. The PSP-EUP boundary at this location appears to be very steep, as indicated by seismicity, and the contact zone is likely in the middle or lower crust of the EUP and/or against the remnant EUP slab.

5. Our set of transects indicate an evolution from thin-skinned processes in the south to a more lithospheric-scale collision in the north. The remarkable continuity of Central Range geologic units suggests a regional process of emplacement, the most plausible of which is regional subduction of transitional and continental margin crust followed by subsequent detachment within the crust. We favor the interpretation that uplift of the Central Range is due to buoyancy of detached crustal slice(s), geometry of the underlying fault zones (i.e., thrust ramps), and, perhaps most importantly, continued continental underthrusting.

6. The specific properties of Taiwan's deep crustal structure remain unknown. Better definition of the crustal thickness and velocity structure across the entire orogen are required to accurately determine the style of deformation. Furthermore, imaging via seismic reflection, magnetotellurics, detailed seismicity studies, or other means is necessary to confirm the locations of major active fault boundaries across Taiwan at all crustal levels. Finally, studies of upper mantle properties are also necessary to show the degree of mantle involvement in the collision process and indicate collision-related mantle flow patterns.

\section{Acknowledgments}

We thank the captain, crew, and science staff of the R/V Maurice Ewing for their perseverance during the typhoon-plagued EW95-09 cruise. The Ewing airgun source is definitely one of the keys to this project. We also thank the captain and crew and science party of the R/V Ocean Researcher I, who performed extremely well during deployment and recovery of the OBSs. The bathymetry shown in Fig. 1 comes primarily from Liu et al. (1998). We thank Dr. Francis Wu for many helpful discussions and for supplying us with the TAICRUST land data to allow the combined onshore/offshore tomographic inversions. We thank those responsible for the land station recording, including (but not limited to) Dr. Y.H. Yeh, Dr. R.J. Rau, Dr. R.C. Shih, and Dr. Francis Wu. We thank Dr. Y. Font for several helpful discussions and sharing her excellent $\mathrm{PhD}$ dissertation with us. We appreciate the efforts of those who processed the MCS data used here, including Dr. P. Schnürle, Dr. W.-C. Chi, Dr. Z. Zhao, and Dr. G.F. Moore. We thank Dr. D. Reed for supplying copies of the southern TAICRUST MCS data. Finally, we are indebted to J.-C. Sibuet and an anonymous reviewer who provided much constructive criticism, which considerably improved the quality, accuracy, and figures in this paper. This work was supported by a grant from the U.S. National Science Foundation (OCE-9417411) to McIntosh and Nakamura, NSF support to other TAICRUST PIs, and NSC support in Taiwan to Chen, Liu, Shih, and Wang. We acknowledge publication support from the University of Texas at Austin Geology Foundation. This is UTIG contribution \#1746. 


\section{References}

Angelier, J., 1986. Preface to the special issue of Geodynamics of the Eurasian-Philippine Sea plate boundary. Tectonophysics 125, IX $-X$.

Berndt, C., Moore, G.F., 1999. Dependence of multiple-attenuation techniques on the geologic setting: a case study from offshore Taiwan. Lead. Edge 18, 74-80.

Biju-Duval, B., Le Quellec, P., Mascle, A., Renard, V., Valery, P., 1982. Multibeam bathymetric survey and high resolution seismic investigations on the Barbados ridge complex (eastern Caribbean): a key to the knowledge and interpretation of an accretionary wedge. Tectonophysics $86,275-304$.

Bos, A.G., Spakman, W., Nyst, M.C.J., 2003. Surface deformation and tectonic setting of Taiwan inferred from a GPS velocity field. J. Geophys. Res. 108 (B10), 2458, doi:10.1029/ 2002JB002336.

Bowin, C., Lu, R.S., Lee, C.-S., Schouten, H., 1978. Plate convergence and accretion in Taiwan-Luzon region. AAPG Bull. 62, 1645-1672.

Byrne, D.E., 1993. Mechanical role of backstops in the growth of forearcs. Tectonics 12, 123-144.

Carena, S., Suppe, J., Kao, H., 2002. Active detachment of Taiwan illuminated by small earthquakes and its control of first-order topography. Geology 30, 935-938.

Chai, B.H.T., 1972. Structure and tectonic evolution of Taiwan. Am. J. Sci. 272, 389-422.

Chang, C.P., Angelier, J., Huang, C.Y., Liu, C.-S., 2001. Structural evolution and significance of a melange in a collision belt: the Lichi Melange and the Taiwan arc-continent collision. Geol. Mag. 138, 633-651.

Chang, C.-P., Angelier, J., Lee, T.-Q., Huang, C.-Y., 2003. From continental margin extension to collision orogen: structural development and tectonic rotation of the Hengchun peninsula, southern Taiwan. Tectonophysics 361, 61-82.

Chemenda, A., Yang, R., Hsieh, C.H., Groholsky, A., 1997. Evolutionary model for the Taiwan collision based on physical modeling. Tectonophysics 274, 253-274.

Chemenda, A.I., Yang, R.-K., Stephan, J.-F., Konstantinovskaya, E.A., Ivanov, G.M., 2001. New results from physical modelling of arc-continent collision in Taiwan: evolutionary model. Tectonophysics 333, 159-178.

Chen, A.T., Nakamura, Y., 1998. Velocity structure beneath eastern offshore of southern Taiwan based on OBS data and its tectonic significance. Terr. Atmos. Oceanol. 9, 409-424.

Cheng, W.B., Wang, C., Shyu, C.T., Shin, T.C., 1998. A threedimensional $\mathrm{Vp}$ model of the southeastern Taiwan area and its tectonic implications. Terr. Atmos. Oceanol. 9, 425-452.

Clark, M.B., Fisher, D.M., Lu, C.Y., Chen, C.H., 1993. Kinematic analyses of the Hseuhshan Range, Taiwan; a large-scale pop-up structure. Tectonics 12, 205-218.

Davies, J.H., von Blanckenburg, F., 1995. Slab breakoff: a model of lithosphere detachment and its test in the magmatism and deformation of collisional orogens. Earth Planet. Sci. Lett. 129, $85-102$.

Font, Y., Liu, C.-S., Schnurle, P., Lallemand, S., 2001. Constraints on backstop geometry of the southwest Ryukyu subduction based on reflection seismic data. Tectonophysics $333,135-158$.

Font, Y., Kao, H., Liu, C.-S., Chiao, L.-Y., 2003. A comprehensive 3D seismic velocity model for the eastern Taiwan-southernmost Ryukyu regions. Terr. Atmos. Oceanol. 14, 159-182.

Hetland, E.A., Wu, F.T., 1998. Deformation of the Philippine Sea plate under the Coastal Range, Taiwan: results from an offshore-onshore seismic experiment. Terr. Atmos. Oceanol. 9, 363-378.

Hetland, E.A., Wu, F.T., 2001. Crustal structures at the intersection of the Ryukyu Trench with the arc-continent collision in Taiwan: results from an offshore-onshore seismic experiment. Terr. Atmos. Oceanol. 12, 231-248.

Hildebrand, R.S., Bowring, S.A., 1999. Crustal recycling by slab failure. Geology 27, 11-14.

Ho, C.S., 1986. A synthesis of the geologic evolution of Taiwan. Tectonophysics $125,1-16$.

Hsu, S.-K., Sibuet, J.-C., Monti, S., Shyu, C.-T., Liu, C.-S., 1996. Transition between the Okinawa trough backarc extension and the Taiwan collision: new insights on the southernmost Ryukyu subduction zone. Mar. Geophys. Res. 18, 163-187.

Hsu, Y.-J., Simons, M., Yu, S.-B., Kuo, L.-C., Chen, H.-Y., 2003. A two-dimensional dislocation model for interseismic deformation of the Taiwan mountain belt. Earth Planet. Sci. Lett. 211, 287-294.

Hu, J.-C., Yu, S.-B., Angelier, J., Chu, H.-T., 2001. Active deformation of Taiwan from GPS measurements and numerical simulations. J. Geophys. Res. 106, 2265-2280.

Huang, C.Y., Wu, W.Y., Chang, C.P., Tsao, S., Yuan, P.B., Lin, C.W., Xia, K.Y., 1997. Tectonic evolution of accretionary prism in the arc-continent collision terrane of Taiwan. Tectonophysics 281, 31-51.

Kao, H., Chen, W.-P., 1991. Earthquakes along the Ryukyu-Kyushu arc: strain segmentation, lateral compression, and the thermo mechanical state of the plate interface. J. Geophys. Res. 96, $21443-21485$.

Kao, H., Jian, P.-R., 2001. Seismogenic patterns in the Taiwan region: insights from source parameter inversion of BATS data. Tectonophysics 333, 179-198.

Kao, H., Shen, S.J., Ma, K.-F., 1998. Transition from oblique subduction to collision: earthquakes in the southernmost Ryukyu arc-Taiwan region. J. Geophys. Res. 103, 7211-7229.

Kao, H., Huang, G.-C., Liu, C.-S., 2000. Transition from oblique subduction to collision in the northern Luzon arc-Taiwan region: constraints from bathymetry and seismic observations. J. Geophys. Res. 105, 3059-3079.

Lallemand, S.E., Liu, C.-S., Dominguez, S., Schnürle, P., Malavieille, J., ACT Scientific Crew, 1999. Trench parallel stretching and folding of forearc basins and lateral migration of the accretionary wedge in the southern Ryukyus: a case of strain partition caused by oblique convergence. Tectonophysics 18, 231-247.

Lallemand, S.E., Font, Y., Bijwaard, H., Kao, H., 2001. New insights on 3-D plate interactions near Taiwan from tomography and tectonic implications. Tectonophysics 335, 229-253.

Lee, J.-C., Angelier, J., Chu, H.-T., 1997. Polyphase history and kinematics of a complex major fault zone in the northern Taiwan mountain belt: the Lishan Fault. Tectonophysics 274, 97-115. 
Liu, C.-S., Schnürle, P., Lallemand, S., Reed, D., 1997. Crustal structures of the Philippine Sea plate near Taiwan. International Conference and Sino-American Symposium on Tectonics of East Asia, Programme and Abstracts, pp. 54-55, Chung-Li, Taiwan.

Liu, C.-S., Liu, S.-Y., Lallemand, S., Lundberg, N., Reed, D., 1998. Digital elevation model offshore Taiwan and its tectonic implications. Terr. Atmos. Oceanol. 9, 705-738.

Loevenbruck, A., Cattin, R., Le Pichon, X., Courty, M.-L., Yu, S.-B., 2001. Seismic cycle in Taiwan derived from GPS measurements. C. R. Acad. Sci., Ser. II 333, 57-64.

Lundberg, N., Reed, D., Liu, C., Lieske, J., 1997. Forearc-basin closure and arc accretion in the submarine suture zone south of Taiwan. Tectonophysics 274, 5-23.

Malavieille, J., Lallemand, S., Dominguez, S., Deschamps, A., Lu, C., Liu, C.-S., Schnürle, P., ACT scientific crew, 2002. Arccontinent collision in Taiwan: new marine observations and tectonic evolution. In: Byrne, T.B., Liu, C.S. (Eds.), Geology and Geophysics of an Arc-Continent Collision, Spec. Pap.Geol. Soc. Am. vol. 358, pp. 187-211.

McIntosh, K.D., Nakamura, Y., 1998a. Crustal structure beneath the Nanao forearc basin from TAICRUST MCS/OBS Line 14. Terr. Atmos. Oceanol. 9, 345-362.

McIntosh, K.D., Nakamura, Y., 1998b. OBS-derived velocity structure of the westernmost Ryukyu arc (abstract). EOS Trans. AGU 79, W74.

Nakamura, Y., McIntosh, K., Chen, A.T., 1998. Preliminary results of a large offset seismic survey west of Hengchun Peninsula, southern Taiwan. Terr. Atmos. Oceanol. 9, 395-408.

Nissen, S., Hayes, D., Buhl, P., Diebold, J., Bochu, Y., Weijun, Z., Yongqin, C., 1995. Deep penetration seismic soundings across the northern margin of the South China Sea. J. Geophys. Res. $100,22407-22433$.

Pin, Y., Zhou, D., Liu, Z., 2001. A crustal structure profile across the northern continental margin of the South China Sea. Tectonophysics 338, 1-21.

Rau, R., Wu, F., 1995. Tomographic imaging of lithospheric structures under Taiwan. Earth Planet. Sci. Lett. 133, 517-532.

Reed, D.L., Lundberg, N., Liu, C.S., Kuo, B.Y., 1992. Structural relations along the margins of the offshore Taiwan accretionary wedge. Acta Geol. Taiwan. 30, 105-122.

Roecker, S.W., Yeh, Y.H., Tsai, Y.B., 1987. Three-dimensional P and $\mathrm{S}$ wave velocity structures beneath Taiwan: deep structure beneath an arc-continent collision. J. Geophys. Res. 92, $10547-10570$.

Schnürle, P., Liu, C.S., Lallemand, S.E., Reed, D.L., 1998. Structural controls of the Taitung Canyon in the Huatung Basin east of Taiwan. Terr. Atmos. Oceanol. 9, 453-472.

Shih, R.C., Lin, C.H., Lai, H.L., Yeh, Y.H., Huang, B.S., Yen, H.Y., 1998. Preliminary crustal structures across central Taiwan from modeling of the onshore-offshore wide-angle seismic data. Terr. Atmos. Oceanol. 9, 317-328.

Sibuet, J.-C., Hsu, S.-K., 2004. How was Taiwan created? Tectonophysics 379, 159-181.

Sibuet, J.-C., Hsu, S.-K., Le Pichon, X., Le Formal, J.-P., Reed, D., Moore, G., Liu, C.-S., 2002. East Asia plate tectonics since 15
Ma: constraints from the Taiwan region. Tectonophysics 344, $103-134$.

Stewart, R., Peselnick, L., 1978. Systematic behavior of compressional velocity in Franciscan rocks at high pressure and temperature. J. Geophys. Res. 83, 831-839.

Suppe, J., 1980. A retrodeformable cross section of northern Taiwan. Proc. Geol. Soc. China 23, 46-55.

Suppe, J., 1981. Mechanics of mountain building and metamorphism in Taiwan. Geol. Soc. China, Mem. 4, 67-89.

Suppe, J., 1987. The active Taiwan mountain belt. In: Shaer, J.P., Rodgers, J. (Eds.), Anatomy of Mountain Chains. Princeton University Press, pp. 277-293.

Suppe, J., Namson, J., 1979. Fault-bend origin of frontal folds of the western Taiwan fold-and-thrust belt. Pet. Geol. Taiwan 16, $1-18$.

Taylor, B., Hayes, D., 1983. Origin and history of the South China Sea Basin. The Tectonic and Geologic Evolution of Southeast Asian Seas and Islands, Part 2, AGU Geophys. Monogr., vol. 27, pp. 23-56.

Teng, L.S., 1990. Geotectonic evolution of late Cenozoic arccontinent collision in Taiwan. Tectonophysics 183, 57-76.

Teng, L.S., 1996. Extensional collapse of the northern Taiwan mountain belt. Geology 24, 949-952.

Teng, L.S., Wang, Y., Tang, C.H., Huang, C.Y., Huang, T.C., Yu, M.S., Ke, A., 1991. Tectonic aspects of the Paleogene depositional basin of northern Taiwan. Proc. Geol. Soc. China 34 (4), 313-336.

Teng, L.S., Lee, C.T., Tsai, Y.B., Hsiao, L.Y., 2000. Slab break off as a mechanism for flipping subduction polarity in Taiwan. Geology 28, 155-158.

Tillman, K., Byrne, T.B., 1995. Kinematic analysis of the Taiwan slate belt. Tectonics 14, 322-341.

Van den Beukel, J., 1992. Some thermomechanical aspects of the subduction of continental lithosphere. Tectonics 11, 316-329.

Wang, T.K., Chiang, C.H., 1998. Imaging of arc-arc collision in the Ryukyu forearc region offshore Hualien from TAICRUST OBS Line 16. Terr. Atmos. Oceanol. 9, 329-344.

Wang, T.K., McIntosh, K., Nakamura, Y., Liu, C.-S., Chen, H.W., 2002. Velocity-interface structure of the southwestern Ryukyu subduction zone from EW9509-1 OBS/MCS data. Mar. Geophys. Res. 22, 265-287.

Wang, T.K., Lin, S.-F., Liu, C.-S., Wang, C., 2004. Crustal structure of the southernmost Ryukyu subduction zone: OBS, MCS and gravity modeling. Geophys. J. Int. 157, 147-163.

Westbrook, G.K., 1982. The Barbados ridge complex: tectonics of a mature forearc system. In: Leggett, J.K. (Ed.), Trench-Forearc Geology: Sedimentation and Tectonics on Modern and Ancient Active Plate Margins, Spec. Publ.-Geol. Soc. Lond., vol. 10, pp. 275-290.

Wu, F., Rau, R., Salzberg, D., 1997. Taiwan orogeny: thin-skinned or lithospheric collision. Tectonophysics 274, 191-220.

Yang, Y.S., Wang, T.K., 1998. Crustal velocity variation of the western Philippine Sea Plate from TAICRUST OBS/MCS Line 23. Terr. Atmos. Oceanol. 9, 379-393.

Yeh, Y.H., Shih, R., Lin, C., Liu, C., Yen, H., Huang, B., Liu, C., Chen, P., Huang, C., Wu, C., Wu, F., 1998. Onshore/offshore 
wide-angle deep seismic profiling in Taiwan. Terr. Atmos. Oceanol. 9, 301-316.

Yu, S.-B., Chen, H.Y., Kuo, L.C., 1997. Velocity field of GPS stations in the Taiwan area. Tectonophysics 274, 41-59.

Yu, S., Kuo, L.-C., Punongbayan, R.S., Ramos, E.G., 1999. GPS observation of crustal deformation in the Taiwan-Luzon region. Geophys. Res. Lett. 26, 923-926.
Zelt, C.A., 1998. Lateral velocity resolution from three-dimensional seismic refraction data. Geophys. J. Int. 135, 1101-1112.

Zelt, C., Barton, P., 1998. Three-dimensional seismic refraction tomography; a comparison of two methods applied to data from the Faeroe Basin. J. Geophys. Res. 103, 7187-7210.

Zelt, C.A., Smith, R.B., 1992. Seismic traveltime inversion for a 2D crustal velocity structure. Geophys. J. Int. 108, 16-34. 